\title{
Extended-Burnup LWR Fuel: \\ The Amount, Characteristics, and Potential Effects on Interim Storage
}

March 1989

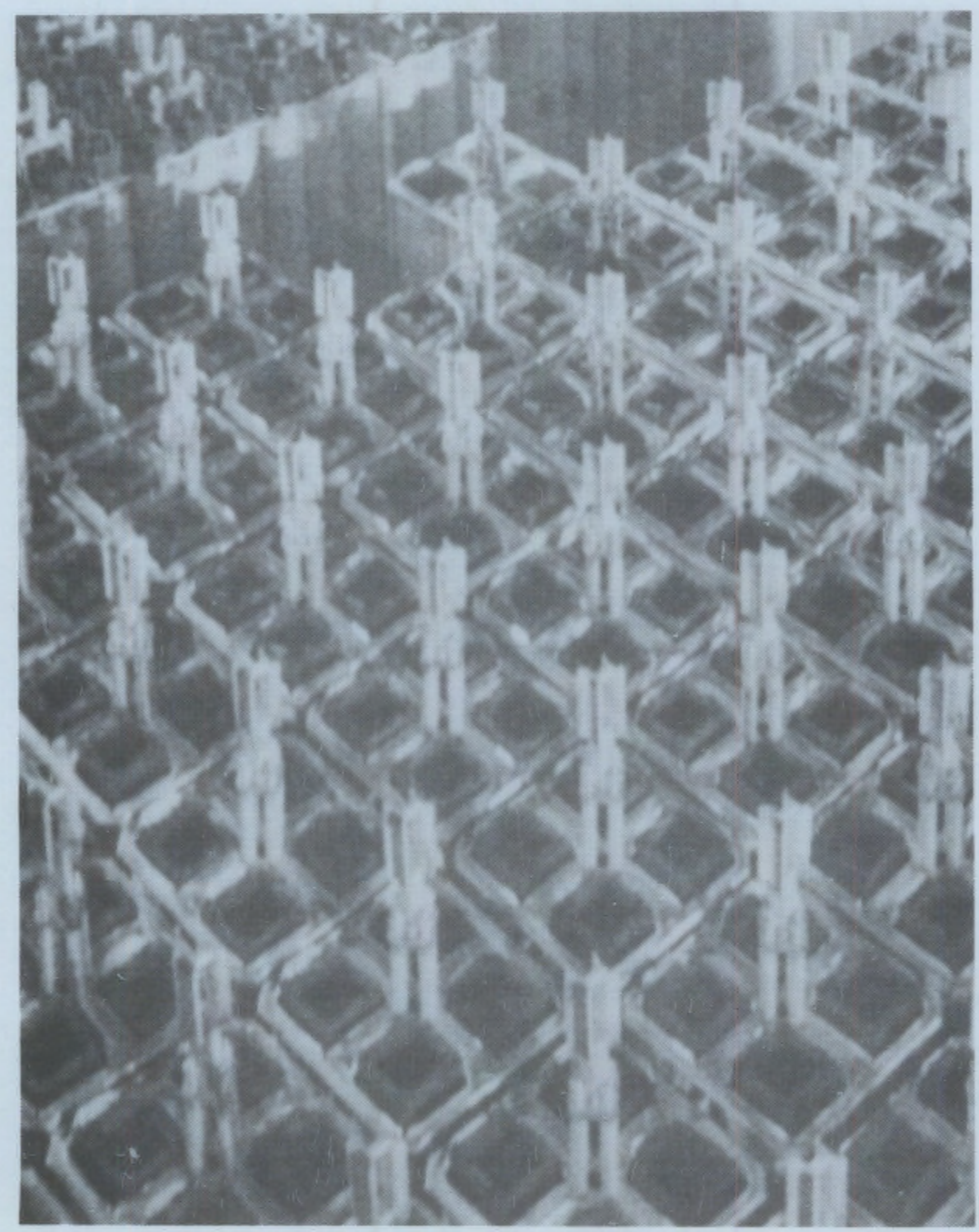

Prepared for the U.S. Department of Energy under Contract DE-AC06-76RLO 1830

Pacific Northwest Laboratory Operated for the U.S. Department of Energy by Battelle Memorial Institute 


\title{
DISCLAIMER
}

This report was prepared as an account of work sponsored by an agency of the United States Government. Neither the United States Government nor any agency thereof, nor Battelle Memorial Institute, nor any or their employees, makes any warranty, expressed or implied, or assumes any legal liability or responsibility for the accuracy, completeness, or usefulness of any information, apparatus, product, or process disclosed, or represents that its use would not infringe privately owned rights. Reference herein to any specific commercial product, process, or service by trade name, trademark, manufacturer, or otherwise does not necessarily constitute or imply its endorsement, recommendation, or favoring by the United States Government or any agency thereof, or Battelle Memorial Institute. The views and opinions of authors expressed herein do not necessarily state or reflect those of the United States Government or any agency thereof.

\author{
PACIFIC NORTHWEST LABORATORY \\ operated by \\ BATTELLE MEMORIAL INSTITUTE \\ for the \\ UNITED STATES DEPARTMENT OF ENERGY \\ under Contract DE-AC06-76RLO 1830
}

\author{
Printed in the United States of America \\ Available from \\ National Technical Information Service \\ United States Department of Commerce \\ 5285 Port Royal Road \\ Springfield, Virginia 22161 \\ NTIS Price Codes \\ Microfiche A01 \\ Printed Copy
}

$\begin{array}{lc}\begin{array}{c}\text { Pages } \\ 001-025\end{array} & \begin{array}{c}\text { Price } \\ \text { Codes } \\ 026-050\end{array} \\ 051-075 & \text { A02 } \\ 076-100 & \text { A03 } \\ 101-125 & \text { A04 } \\ 126-150 & \text { A05 } \\ 151-175 & \text { A06 } \\ 176-200 & \text { A07 } \\ 201-225 & \text { A08 } \\ 226-250 & \text { A09 } \\ 251-275 & \text { A10 } \\ 276-300 & \text { A11 } \\ & \text { A12 } \\ & \text { A13 }\end{array}$


EXTENDED-BURNUP LWR FUEL: THE AMOUNT, CHARACTERISTICS, AND POTENTIAL EFFECTS ON INTERIM STORAGE

W. J. Bailey

March 1989

Prepared for the U.S. Department of Energy under Contract DE-AC06-76RLO 1830

Pacific Northwest Laboratory

Richland, Washington 99352 
. 


\section{ABSTRACT}

The results of a study on extended-burnup, light-water reactor (LWR) spent fuel are described in this report. The study was performed by Pacific Northwest Laboratory for the U.S. Department of Energy (DOE). The purpose of the study was to collect and evaluate information on the status of in-reactor performance and integrity of extended-burnup LWR fue 1 and initiate the investigation of the effects of extending fuel burnup on the subsequent handling, interim storage, and other operations (e.g., rod consolidation and shipping) associated with the back end of the fuel cycle. The results of this study will aid DOE and the nuclear industry in assessing the effects on waste management of extending the useful in-reactor life of nuclear fuel.

Of the approximately 51,000 spent LWR fuel assemblies currently in storage in domestic facilities, it is estimated (based on DOE's CY-1986 data) that there are $-11,000$ assemblies with burnups of $\geq 30,000$ MWd/MTIHM. (a) of the $-11,000$ assembTies, -200 (b) have burnups of $\geq 40,000 \mathrm{MWd} / \mathrm{MTIHM}$, and of the -200 assemblies, 9 have burnups of $\geq 50,000$ MNd/MTIHM.

The experience base with extended-burnup fuel is now substantial and projections for future use of extended-burnup fuel in domestic LWRs are positive. The basic performance and integrity of the fuel in the reactor has not been compromised by extending the burnup, and the potential limitations for further extending the burnup are not severe. However, a potential concern for extended-burnup fuel in the reactor is waterside corrosion of the fuel cladding. Anticipated changes in the characteristics of the LWR fuel assemblies as a result of extended burnup are not expected to jeopardize the spent fuel during storage in water. It was concluded in an earlier DOEsponsored study (c) that both boiling water reactor (BWR) and pressurized water reactor (PWR) fuel assemblies with burnups up to $45 \mathrm{GWd}$ /MTIHM should present no problems (i.e., that are related to the strength of their main structural components) for handling in spent fuel storage pools or during

(a) Megawatt-days per metric ton of initial heavy metal (MWd/MTIHM).

(b) More recent data indicate that this number is now $\sim 500$.

(c) Conducted in 1986 by S. M. Stoller Corporation. 
handling associated with the back end of the fuel cycle. The results of the current study by Pacific Northwest Laboratory indicate that PWR fuel assemblies with peak assembly burnups to $50 \mathrm{GWd} / \mathrm{MTIHM}$ should present no problems for handling in pools, etc. 


\section{EXECUTIVE SUMMARY}

In 1984, the U.S. Department of Energy (DOE) programs involving extended-burnup fue 7 were reviewed by the General Accounting Office (GAO). ${ }^{(1,2)}$ At that time, GAO stated that extended-burnup fuel needs to be factored into waste management pianning and repository design so that quantities of spent fuel that DOE will need to store and the associated facility and service requirements will not be overestimated. Since that time, information on a number of fuel assemblies that have attained higher burnups has become or is becoming available. In response to $\mathrm{GAO}^{\prime} \mathrm{s}$ recommendation, and to aid DOE and industry in fully assessing the effects on waste management of extending the useful in-reactor life of light-water reactor (LWR) fuel, a study was performed under the Commercial Spent Fuel Management (CSFM) Program, which is sponsored by DOE and managed by the Pacific Northwest Laboratory (PNL). The objectives of the study were to 1) collect and evaluate information on the status of the in-reactor performance and integrity of extended-burnup LWR fue 1,2 ) initiate the investigation of the effects of extending burnup on the subsequent handling and storage of the associated spent fuel, and 3) disseminate this information. Included in this report are discussions of 1) the experience base with extended-burnup fuel, including estimates of the numbers of intact and failed or damaged extended-burnup fuel assemblies currently in storage and projections of future use of extended-burnup fue 1, 2) the performance, integrity, and potential limitations of extended burnup fuel in the reactor, and 3 ) the effect of extended-burnup fuel on subsequent handling, storage, and other operations (e.g., rod consolidation and shipping) associated with the back end of the fuel cycle.

It is estimated, ${ }^{(3)}$ based on CY-1986 data supplied by utilities on Form RW-859 to DOE's Energy Information Administration (EIA), that the following higher burnup fuel assemblies are among the $-51,000$ fuel assemblies ( $97 \%$ contain Zircaloy-clad fuel; $3 \%$ contain stainless steel-clad fuel) that are currently in storage in domestic facilities: 


\begin{tabular}{rr} 
Burnup, ${ }^{(a)}$ MWd/MTIHM & $\begin{array}{r}\text { No. of Fue } \\
\text { Assemblies }\end{array}$ \\
\hline 30,000 to $<35,000$ & 8,532 \\
35,000 to $<40,000$ & 2,494 \\
40,000 to $<45,000$ & 190 \\
45,000 to $<50,000$ & 5 \\
50,000 to $<55,000$ & $\frac{9}{11,230}$ \\
& Total
\end{tabular}

(a) Megawatt-days per metric ton of initial heavy metal.

Included among the 11,230 fuel assemblies with burnups of 30,000 MWd/MTIHM or higher are 191 defective (failed or damaged) assemblies, of which 149 have burnups of 30,000 to $35,000 \mathrm{MWd} / \mathrm{MTIHM}, 38$ have burnups of 35,000 to $40,000 \mathrm{MWd} / \mathrm{MTIHM}$, and 4 have burnups of 40,000 to $45,000 \mathrm{MWd} / \mathrm{MT}$ IHM. (3)

Implementation of burnup extension by utilities is proceeding in a stepwise fashion. (4) In the most ambitious cases, the highest PWR discharge batch burnups for fuel already ordered or loaded is 45,000 MWd/MTIHM. However, more moderate burnup extension is very widespread, with over $80 \%$ of the LWRs in the United States extending burnup by at least $10 \%$ over the traditional values of the 1970's or having made decisions to do so in immediate future cycles. $(4,5)$

Overall domestic fuel operating experience continues to be excellent: current fuel rod reliabilities are typically $>99.99 \%$, which corresponds to fuel rod failure rates of $<0.01 \%$. ${ }^{(3)}$ The failure rate of fuel rods is not anticipated to increase as burnup is extended. $(6,7)$ To date, no evidence of a degradation in fuel performance or safety has been detected in extendedburnup fuel operating experience with experimental and test fuel assemblies up to the burnup levels currentiy approved by the U.S. Nuclear Regulatory Commission (NRC). ${ }^{(8)}$ NRC generic approvals are for batch-average burnups of 35 to $40 \mathrm{GWd} / \mathrm{MTIHM}$ and 40 to $45 \mathrm{GWd} / \mathrm{MTIHM}$ for BWRs and PWRs, respectively. The results from DOE programs to increase fuel burnup indicate that no significant unexpected phenomena or trends that would limit burnups to lower 
levels have been encountered in the burnup ranges studied with fuel of both traditional and advanced designs. (4) Also, good design and licensing data, which are of benefit to the nuclear industry, have been obtained on fuel that has been irradiated to high burnup levels. The only known occurrence in the United States of failure of fuel operating in the extended burnup range took place in a core having many debris-induced failures of fuel of traditional design. ${ }^{(4)}$

For most of the fuel performance parameters, a good data base exists for burnups up to $34 \mathrm{GWd} /$ MTIHM and $47 \mathrm{GWd}$ /MTIHM for BWR fuel and PWR fuel, respectively--the exception is irradiation-induced growth of Zircaloy-clad fuel rods and the associated fuel assemblies. (9)

Anticipated changes in the characteristics of the LWR fuel assemblies as a result of extended burnup are not expected to jeopardize the spent fuel during storage in water. ${ }^{(10)}$ NRC Regulatory Guide 1.25 (including the supplemental NRC memorandum of December 20, 1982) does not provide sufficient guidance in analyzing fuel handling accidents involving fuel with burnups greater than 38,000 MWd/MTIHM. (11) Handling and reconstitution(a) experience with extended-burnup fuel deserves some attention to prepare for future rod consolidation campaigns. (12) The impact of spent, extended-burnup LWR fuel assemblies on handling has been evaluated in an earlier study ${ }^{(9)}$ and it was concluded (based on available data) that both BWR and PWR fuel assemblies with burnups up to $45 \mathrm{GWd} /$ MTIHM should present no problems (i.e., that are related to the strength of their main structural components) for handling in spent fuel storage pools or during handling associated with the back end of the fuel cycle. The results of the current PNL study indicate that PWR fuel assemblies with peak assembly burnups to $50 \mathrm{GWd} / \mathrm{MTIHM}$ should present no problems for handling at pools, etc. Designers of rod consolidation equipment will have to provide sturdier equipment to accommodate the harder materials (a result of irradiation) associated with extended-burnup fuel. ${ }^{(6)}$ The

(a) Reconstitution of an irradiated fuel assembly involves removal and replacement of defective fuel rods to permit the assembly to be returned to reactor service. 
irradiated materials (e.g., the nonfuel-bearing components) have been more difficult to cut than the unirradiated materials. (13-15)

The useful in-reactor life of nuclear fuel for LWRs has been extended over the past decade with positive results. The experience base with extended-burnup fuel is now substantial and projections for future use are positive. The basic performance and integrity of the fuel in the reactor has not been compromised by extending the burnup, and the potential limitations for further extending the burnup are not severe. However, a potential concern for extended-burnup fuel in the reactor is waterside corrosion of the fuel cladding. (4) 


\section{ACKNOWLEDGMENTS}

This report summarizes the results of a study conducted by the Pacific Northwest Laboratory (PNL) for the Commercial Spent Fuel Management (CSFM) Program, which is sponsored by the U.S. Department of Energy (DOE) under Contract DE-ACO6-76RL0 1830. The author acknowledges the contribution by $R$. $C$. Walling of the Waste Systems Department in assisting in the collecting of pertinent data. GratefuT appreciation is expressed to DOE for guidance and support on the study. 
.4 


\section{CONTENTS}

ABSTRACT .........................

EXECUTIVE SUMMARY .................. v

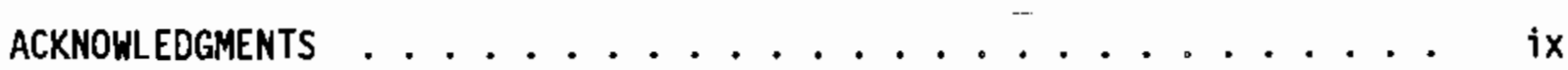

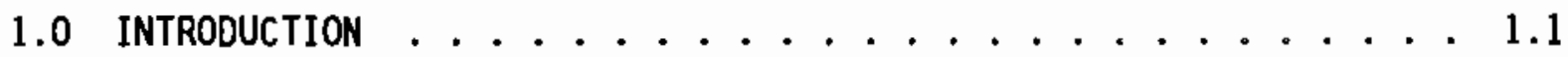

2.0 CONCLUSIONS AND RECOMMENDATIONS . . . . . . . . . 2.1

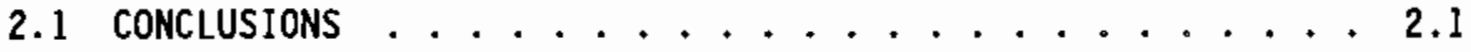

2.1.1 Experience Base with Extended-Burnup Fuel . . . . . 2.1

2.1.2 Performance, Integrity, and Potential Limitations . . 2.3

2.1 .3 Effects on Operations ............ 2.7

2.2 RECOMMENDATIONS ...............................

2.2.1 Experience Base with Extended-Burnup Fue 1 . . . 2.10

2.2.2 Performance, Integrity, and Potential Limitation .. 2.10

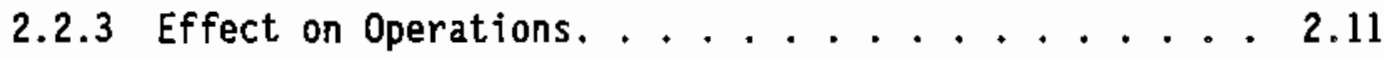

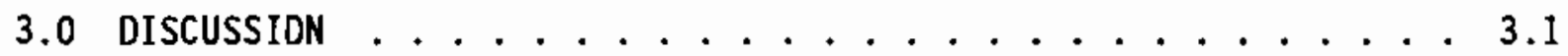

3.1 EXPERIENCE BASE WITH EXTENDED-BURNUP FUEL . . . . . . 3.1

3.1.1 Estimated Number of Extended-Burnup Fue1

Assembl jes Currently in Storage ......... 3.1

3.1.2 Estimated Number of Failed or Damaged ExtendedBurnup Fuel Assemblies Currentiy in Storage . . . 3.4

3.1.3 Projections of Future Use of ExtendedBurnup FueT . . . . . . . . . 3.8

3.2 PERFORMANCE, INTEGRITY, AND POTENTIAL LIMITATIONS OF EXTENDED-BURNUP FUEL . . . . . . . . . . . 3.9

3.2.1 Performance and Integrity of Extended-Burnup Fue 1 . 3.11

3.2.2 Potential Limitations of Extended-Burnup Fue1 . . . 3.20

3.3 EFFECT OF EXTENDED-BURNUP FUEL ON HANDLING, STORAGE, AND

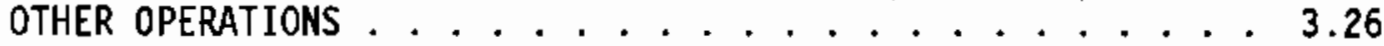




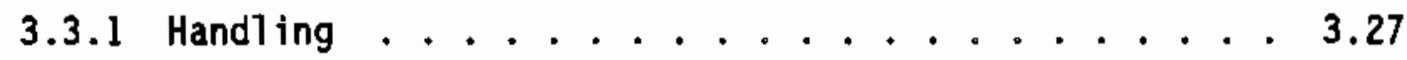

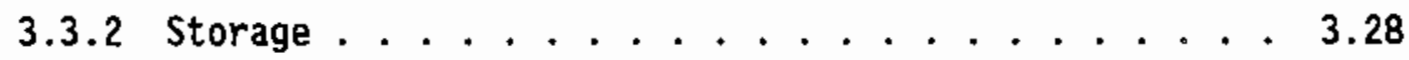

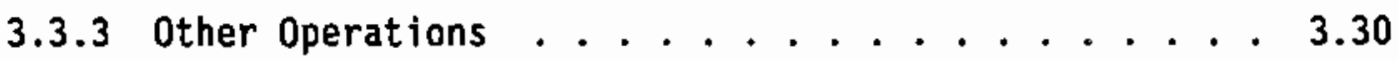

4.0 REFERENCES .................... 4.1 


\section{TABLES}

3.1 Cumulative Number (through December 31, 1986) of BWR and

PWR Fuel Assemblies and Fuel Rods that have Been Irradiated

and Discharged and that Are Currently Being Irradiated . . . . 3.2

3.2 Burnup Ranges for Permanently Discharged BWR and PWR Spent

Fuel in Storage at Domestic Sites............ . . 3.3

3.3 U.S. Experience with Extended-Burnup Fuel Rods . . . . . . . . . 3.4

3.4 Permanently Discharged BWR Spent Fuel With the Highest

Average Burnup ................... 3.5

3.5 Permanently Discharged PWR Spent Fuel With the Highest

Average Burnup . . . . . . . . . . . . . . . 3.6

3.6 Weighted Average Burnup for Permanently Discharged Spent Fuel . . 3.7

3.7 Burnup Distribution for Defective U.S. Fuel Assemblies with

Burnups of 25,000 MWd/MTIHM or Higher . . . . . . . . 3.8

3.8 Quantities of Spent Fuel by Age in 1990 and Discharge Exposure ..................... 3. . . . . . . . . . .

3.9 LWR Fuel Irradiated to Extended-Burnup Levels . . . . . . . . 3.12

3.10 Performance Considerations for LWR Fuel Assemblies for Extended Burnup .................... 3. . . . . . . . .

3.11 Parameters Affected by Extending Fue] Burnup . . . . . . . . 3.15

3.12 Summary of Potential Limitations for Extended Burnup of

BWR Fuel..................... 3.21

3.13 Summary of Potential Limitations for Extended Burnup of PWR Fuel. . . . . . . . . . . . . . . . . . 3.23

3.14 Projected Cumulative Storage Requirements in the U.S. . . . . . 3.28

3.15 Burnup-Enhanced Fuel Phenomena and Impacts on the Design of Rod Consolidation Equipment .............. 3.30 



\subsection{INTRODUCTION}

The General Accounting Office (GAO) reviewed the U.S. Department of Energy (DOE) programs and indicated in 1984 that extended-burnup fuel needs to be factored into waste management planning and repository design. $(1,2)$ At that time, GAO stated that this should be done so that quantities of spent fuel that DOE will need to store and the associated facility and service requirements will not be overestimated. Since that time, information on a number of fuel assemblies that have attained higher burnups has been published and additional information will gradually become available. In response to $\mathrm{GAO}^{\prime}$ s recommendation, and to aid DOE and industry in fully assessing the effects on waste management of extending the useful life of light-water reactor (LWR) fuel, a study was performed under the Commercial Spent Fuel Management (CSFM) Program, which is sponsored by DOE's Office of Civilian Radioactive Waste Management (OCRWM) and managed by the Pacific Northwest Laboratory (PNL). The objectives of the study were to 1) collect and evaluate information on the status of the in-reactor performance and integrity of extended-burnup LWR fuel, 2) initiate the investigation of the effects of extending burnup on the subsequent handling and storage of the associated spent fuel, and 3 ) disseminate this information. Included in this report are discussions of 1) the experience base with extended-burnup fuel, including estimates of the numbers of intact and failed or damaged extendedburnup fue 7 assemblies currently in storage and projections of future use of extended-burnup fue1, 2) the performance, integrity, and potential limitations of extended-burnup fuel in the reactor, and 3 ) the effect of extendedburnup fuel on subsequent handling, storage, and other operations (e,g., rod consolidation and shipping) associated with the back end of the fuel cycle. 


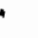




\subsection{CONCLUSIONS AND RECOMMENDATIONS}

The useful in-reactor $7 \mathrm{ife}$ of nuclear fuel for LWRs has been extended over the past decade with positive results. The experience base with extended-burnup fuel is now substantial and projections for future use are positive. The basic performance and integrity of the fuel in the reactor has not been compromised by extending the burnup, and the potential limitations for further extending the burnup are not severe. However, a potential concern for extended-burnup fuel in the reactor is waterside corrosion--according

to Lang, ${ }^{(4)}$ this is probably the phenomenon that will prove ultimately limiting for present cladding metallurgy, for high enough burnup extension, high enough coolant temperature, and/or insufficiently careful water-chemistry control.

Results of examinations suggest that higher fuel burnups are not likely to impose cladding integrity problems during storage in water. ${ }^{(10)}$ Even if extended burnup results in some fuel failures, pool storage technology has a demonstrated capability to cope with them.

Some domestic plant licensees have requested approval to increase their discharge batch average burnup levels above 50,000 MWd/MTIHM; environmentally, this higher burnup would have no significant impact over that of current normat burnup. ${ }^{(16)}$

The following sections present specific conclusions and recommendations noted during this study.

\subsection{CONCLUSIONS}

These are principal conclusions that can be drawn from the study on which this report is based.

\subsubsection{Experience Base with Extended-Burnup Fue1}

Conclusions related to the U.S. inventory of intact and defective (failed or damaged) fuel in storage and to the projected use of extendedburnup fuel are discussed in the three subsections below. 


\subsubsection{Fuel in Storage}

It is estimated, ${ }^{(3)}$ based on DOE/EIA's CY-1986 Form RW-859 data from utilities, that the following higher burnup fuel assemblies are among the $\sim 51,000$ fue 1 assemblies (97\% contain Zircaloy-clad fuel; 3\% contain stainless steel-clad fuel) that are currently in storage in domestic facilities:

\begin{tabular}{cc} 
Burnup (a) MWd/MTIHM & $\begin{array}{c}\text { No. of Fuel } \\
\text { Assemblies }\end{array}$ \\
\cline { 2 - 2 } 30,000 to $<35,000$ & 8,532 \\
35,000 to $<40,000$ & 2,494 \\
40,000 to $<45,000$ & 190 \\
45,000 to $<50,000$ & 5 \\
50,000 to $<55,000$ & Total $\frac{9}{11,230}$
\end{tabular}

(a) Megawatt-days per metric ton of initial heavy metal.

(b) More recent data indicate that -500 fuel assembl ies have burnups $\geq 40,000$ MWd/MT lHM.

\subsubsection{Defective Fuel in Storage}

Among the $-51,000$ fuel assemblies currently in storage, it is estimated ${ }^{(3)}$ that there are this many defective (failed or damaged) assemblies:

\begin{tabular}{lr} 
Burnup, MWd/MTIHM & $\begin{array}{c}\text { No. of Defective } \\
\text { Fuel Assemblies }\end{array}$ \\
\hline 30,000 to 35,000 & 149 \\
35,000 to 40,000 & 38 \\
40,000 to 45,000 & Total $\frac{4}{191}$
\end{tabular}

A utility's fuel was examined recently by three methods: visual inspection, ultrasonic testing, and eddy current testing. The results indicate that if only one or two of those methods had been used, one or more leakers and/or incipient failures could have been inadvertently overlooked. (17) 


\subsubsection{Projected Use of Extended-Burnup Fuel}

Conclusions concerning projections about the future use of extendedburnup fuel in domestic LWRs are listed below:

- For 1990 and beyond, the driving force in the U.S. for developing extended-burnup fuel designs will initially be to decrease the requirements for at-reactor storage of spent fuel and for fuel consolidation; eventually, resolution of fuel cycle flosure may have an effect on further development of such fuel. (18)

- A 1987 paper(4) indicates that implementation of burnup extension by utilities is proceeding in a step-wise fashion. In the most ambitious cases, the highest PWR discharge batch burnups already achieved have exceeded $40,000 \mathrm{MWd} / \mathrm{MT}$ IHM and the highest anticipated burnups for fuel already ordered or loaded is 45,000 MWd/MTIHM. More moderate burnup extension is very widespread: over $80 \%$ of the LWRs in the United States have extended burnup by at least $10 \%$ over the traditional values of the $1970^{\prime}$ s or have made decisions to do so in immediate future cycles, and that trend is anticipated to continue. $(4,5)$ Burnup extensions of about $35 \%$ have been shown to be reasonably achievable. (5)

- In the 1990s, it is anticipated that batch average burnups witl be about $45 \mathrm{GWd} /$ MTIHM and about $60 \mathrm{GWd} /$ MTIHM for boiling water reactors (BWRs) and pressurized water reactors (PWRs), respectively. (19)

\subsubsection{Performance, Integrity and Potential Limitations}

Conclusions related to the performance, integrity and potential limitations of extended-burnup fuel in the reactor are described in the two subsections below.

\subsubsection{Performance and Integrity}

Conclusions regarding the in-reactor performance and integrity of extended-burnup fuel are listed below:

- Average burnup levels have been increasing yearly, but so far, fuel rod failure rates have not exhibited a similar trend. $(20,21)$ The failure rate of fuel rods is not anticipated to increase for extended-burnup fuel. $(6,7)$

- Of the degradation phenomena of concern with extended-burnup fue1, waterside corrosion of the cladding at burnups over $55,000 \mathrm{MWd} / \mathrm{MT}$ IHM remains the issue with no immediate design solution. (22) Howeyer, cladding atloy development programs are in progress. $(4,22-24)$ 
- Overall domestic fuel operating experience continues to be excellent: current fuel rod reliabilities are typica]ly $>99.99 \%$, which corresponds to fuel rod failure rates of $<0.01 \%$. (3)

- Results from DOE programs $(4)$ to increase fue] burnup indicate that no significant unexpected phenomena or trends that would limit burnup to lower leve1s have been encountered in the burnup ranges studied with fuel of both traditional and advanced designs. Also, good design and licensing data, which are of benefit to the nuclear industry, have been obtained on fuel that has been irradiated to high burnup levels. The only known occurrence in the United States of failure of fuel operating in the extended burnup range took place in a core havjog many debris-induced failures of fuel of traditiona T design. (4)

- In spite of further improvements and though fuel reliability has improved substantially in recent years, the nuclear industry has indicated that even higher reliability is of major importance (because of the need to maintain the integrity of the first barrier, the cladding, to release of radioactive products) and will be needed in the future for a wide variety of operating conditions. (I8) From the utjlities' perspectives, good fuel performance is not easily attained. (17)

- The nuclear industry is presently faced with very few major problems with fuel and, as a result, our attention is often directed toward less-frequent problems--and industry has found that lowfrequency fuel failures are often djfficult to locate and to categorize by failure mechanism. (18)

- The NRC has issued generic approvals for batch-average burnups of 35 to $40 \mathrm{GWd} / \mathrm{MIJHM}$ and 40 to. $50 \mathrm{GWd} / \mathrm{MTIHM}$ for BWRs and PWRs, respectively. (8) To date, no evidence of a degradation in fuel performance or safety has been detected in extended burnup fue 1 operating experience with experimental and test fuel assemblies up to those burnup levels.

- Advanced Nuclear Fuels Corporation's data base for high-burnup designs supports batch discharge burnups of $48_{5}$ GWd/MTIHM and $48 \mathrm{GWd} / \mathrm{MT}$ IHM in BWRs and PWRs, respectively. (25)

- Batch-average discharge burnups for Babcock Wilcox Company (B\&W) PWR fuel are now approaching 38 GWd/MTIHM. (26) B\&W fuel is continuing to move toward extended burnups at a rate of $1.3 \mathrm{GWd} / \mathrm{MTIHM}$ per year. Two recent types of B\&W fuel are designed for assembly average burnups of $55 \mathrm{GWd} /$ MTIHM.

- Discharge exposures for Combustion Engineering, Inc., (C-E) PWR fuel have been in the 35 to 45 GWd/MTIHM range; a data base for design and operation of fue 1 to burnups in excess of $50 \mathrm{GWd} / \mathrm{MTIHM}$ has been developed. $(27)$ 
- General Electric Company (GE) has not experienced any new or unique fuel failure mechanism with BWR fuel that is related to burnup or associated with a burnup-related failure threshold. (28) Fuel rod reliabilities of $99.994 \%$ appear achievable with new GE designs for BWR fuel for extended burnup to $38 \mathrm{GWd} / \mathrm{MTIHM}$ (29)

- Successful irradiation of four Hestinghouse Electric Corporation PWR fuel assemblies to a burnup of $55 \mathrm{GHd} / M T I H M$ provided the technical basis for extending the Optimized Fuel Assembly (OFA) demonstration irradiations through five operating cycles. (30)

- A recent(31) nondomestic paper indicates that as yet no technical difficulties have occurred that would prevent rajsing the discharge burnup to a peak pellet value of about 55 GWd/MTIHM.

- Another recent nondomestic paper(32) indicates that the behavior of high burnup fuel is generally good and satisfactory, but is largely affected by fuel rod designs, fabrication parameters, and power histories.

- Nodular corrosion may increase as more BWRs operate in a loadfollowing mode and burnup is increased; Zircaloy corrosion is also a concern for PWRs. (18) Zircaloy cladding corrosion has become limiting in a few newer PWRs that have followed the trend to increase rod power or coolant outlet temperature to improve plant efficiency. (18)

- According to a recent GE paper, (33) as a more statistically significant number of fuel assembly components attain "ultra-high burnups" and fluences, Zircaloy is liable to be pushed to its operating limits.

- Results indicate that the rate of closure (resulting from bowing of fuel rods) between fuel rods decreased with increasing burnup and that af high burnup there was no excessive closure between rods. (18)

- A large variability in the data on fuel rod axial growth is observed at burnups higher than about $20 \mathrm{GWd} / \mathrm{MTIHM}$. (31) To date, no effect on red growth from operating in a load-following mode has been found. (31)

- Results of power ramp (transient) studies(34) in France indicate that no fuel rods have failed at high burnups (29 to $59 \mathrm{GWd} / \mathrm{MTIHM}$ ) and high linear heat generation rates, despite very high cladding strain caused by fuel expansion, high release of fission gas, and oxide structure modifications.

- For most fuel rods, the trend is for the cladding to continuously decrease in diameter (due to creep) up to burnups of 30 to 50 GWd/MTIHM (depending on the fuel type); if rods reach high 
burnup (over $50 \mathrm{GWd} / \mathrm{MTIHM}$ ) and operate at 1 inear heat generation rates around $30 \mathrm{~kW} / \mathrm{m}$ up to a burnup of $70 \mathrm{GWd} / \mathrm{MTIHM}$, then the fue 1 rod diameter strongly increases (due to fuel swelling) and becomes even larger than the initial rod diameter. $(32)$ The residual ductility and fracture resistance of Zircaloy cladding at high burnup is adequate to endure this strain and avoid breaching of the cladding.

- Results from overpower (ramp) tests indicate a rather sharp increase in failure threshold for PWR fyel rods under certain conditions, including very high burnup. (35) However, several very high-burnup PWR fuel rods survived ramp testing beyond the lexel at which failure would be anticipated, based on other findings. (35)

- Extending fuel burnup has emphasized the need for we11-characterized fuel performance data. An important part of such data involyes the release of fission gas during power transients late in ijfe. (36)

- The importance of plant operating environment, in particular water chemistry, on fuel performance has not been well established (e.g., tighter water-chemistry specifications have not improved fuel reliability). (18)

- Adequate performance of barrier fuel at high flyences is currently anticipated but has not yet been demonstrated. (33)

- The West Germans(37) have a complete PWR fuel assembly, which contains fuel rods with burnups of $\leq 43,000 \mathrm{MWd} / \mathrm{MTIHM}$, involved in a dry storage experiment; the analysis of the behavior of the fuel rods in dry storage thus far indicates that the design of their storage facilities (air environment not used) is limited only by the spent fuel insertion temperature and not by the storage method.

- It is concluded in a 1985 report (38) and a 1985 paper(39) that extending burnup even to 60,000 MWd/MTIHM results, in general, in environmental consequences that are either less than or virtually the same as those assumed in current regulations.

\subsubsection{Potential Limitations}

Conclusions pertaining to potential limitations for extended-burnup fue 1 in the reactor are listed below:

- For most of the fuel performance parameters, there currently exists a good data base for burnups up to $34 \mathrm{GWd} / \mathrm{MTIHM}$ and $47 \mathrm{GWd} / \mathrm{MTIHM}$ for BWR fuel and PWR fuel, respectively--the exception is irradiation-induced growth of the Zircaloy-clad fuel rods and the associated fuel assemblies. (9) During licensing, some fuel designs were found to lack data on fuel rod and fuel assembly growth at extended burnups. (8) 
- Fuel rod and assembly bow is affected by differential Zircaloy growth (a potential burnup 1 imit); such growth can also cause bowing of BWR channels. (40)

- Significant decreases in the ductility of highly irradiated Zircaloy fuel cladding, in particular at low temperatures, have been measured. (27) It is not clear whether irradiation damage or hydrogen pickup is the dominant faftor associated with the observed decrease in Zircaloy ductility. (27)

- Bonding of the fuel to the Zircaloy cladding at high burnup increases the fuel rod axial growth rate. As a result, the cladding is forced to creep axial $y$ at a rate that is controlled by the swelling of the fuel pellets. $(27)$

- Pellet-cladding bonding and pellets with porous rims in high-burnup fuel did not have any impact on fission-gas release or pellet swelling. (31)

- According to a recent German paper, (41) fission gas pressure can become a Timiting item for $8 \times 8$ BWR fuel at higher burnups, particularly under the conservative conditions that have to be applied for licensing analysis.

- Waterside corrosion and cladding ductility are considered to be potential problem areas for some plants. (8)

- The corrosion of Zircaloy end plugs is one fuel life-limiting factor at high burnup. (31)

- Crud deposition is of concern when fue1 rod discharge burnups are extended to about 50,000 MWd/MTIHM or higher. (42)

- Waterside corrosion of the cladding may become a life-limiting feature of fuel rod design for these higher burnups ${ }^{2}$ jn particular when combined with daity load-following operation. (42)

- Manufacturing quality is not always consistent and can lead to unanticipated variations in fue . Berformance even after improvements are made in fuel designs. (18)

- The utilities are striving for fuel failure rates of less than one in $10^{5}$ rods (i.e., a reliabj]ify of $>99.999 \%$, which corresponds to a failure rate of $<0.001 \%$. $(18)$

\subsubsection{Effects on Operations}

Conclusions related to the effects of extended-burnup fuel on handing, storage, and other operations (e.g., rod consolidation and shipping) are described in the three subsections below: 


\subsubsection{Handling}

Conclusions concerning the effect of extended-burnup fuel on handling operations subsequent to reactor service are listed below:

- Handling and reconstitution experience with extended-burnup fuel deserves some attention (e.g., collect data on fuel rod and fuel assembly growth) to prepare for future rod consolidation campaigns. (12)

- It would help the nuclear industry if the NRC would update Regulatory Guide 1.25 so it provides additional guidance in analyzing fuel handling accjefpts involving fuel with burnups greater than 38,000 MWd/MTIHM. (II)

- The impact of spent, extended-burnup LWR fuel assemblies on handling was evaluated in a 1986 report: $(9)$ it was concluded (based on available data) that both BWR and PWR fuel assemblies with burnups up to $45 \mathrm{GWd} / \mathrm{MT}$ IHM should present no problems (i.e, . that are related to the strength of their main structural components) for handling in spent fuel storage pools or during handling associated with the back end of the fuel cycle. The current PNL study indicates that PWR fuel assemblies with peak assembly burnups to $50 \mathrm{GWd} / \mathrm{MTIHM}$ should present no problems for handling at pools, etc.

\subsubsection{Storage}

Conclusions regarding the effect of extended-burnup fuel on storage operations subsequent to reactor service are listed below:

- Anticipated changes in the characteristics of the LWR fuel assemblies as a result of extended burnup are not expected to jeopardize the spent fuel during storage in water. (10)

- The quantities of LWR spent fuel discharged decrease as the burnup is increased, which will free up storage space in at-reactor pools. (5)

- Technicar modifications or design changes to accommodate extendedburnup fuel do not unduly stretch the current storage and consolidation egujpment or designs and are economically attractive. (43)

- The main impact of extending fuel burnup on wet and dry storage and rod consolidation is the reduction in the total requirements for fuel storage and in the total quantity of fuel that must be consolidated. (43) other issues that are involved are the design modifications necessary to accommodate the higher initial enrichment, heat load, and source term. ${ }^{43}$ 
- Use of burnup credit in spent fuel storage equipment for extendedburnup fuel can result in the elimination of the use of poison material. This would eliminate the concern about degradation of the poison material over time and exposure. (43)

- Regarding credit for burnup in spent fuel storage rack designs, it should be noted that several experiments have been conducted with nonirradiated fuel that included the major features of fuel racks; however no such experiments have been performed with irradiated fue1. (44)

- There is an uncertainty that needs to be considered in PWR fuel storage racks. Results of criticality studies on the storage of PWR spent fuel reveal that for burnups above about $27,000 \mathrm{MWd} / \mathrm{MTIHM}$, the more highly reactive ends of the fuel assemblies result in a positive reactivity jocrement, an effect that is not observed in the reactor core. $(45)$

- Efforts are underway to qualify fuel handling and stgrage facilities for fuel enrichments up to 5 wt\% uranium-235. (46)

- Crud deposits typically consist of individual agglomerated particles ranging in size from 0.1 to 10 microns. Particulates in that size range would become airborne if they are released during dry fuel handing operations; hence, facij)ity designs must be able
to accommodate such airborne releases. 47$)$

- Whole-core fuel cleaning may become important as more plants try to reduce radiation levels in the future.

\subsubsection{3 $\underline{\text { other }}$}

Conctusions pertaining to the effect of extended-burnup fuel on other operations (e.g., rod consolidation and shipping) subsequent to reactor service are listed below:

- Designers of rod consolidation equipment will have to provide sturdier equipment to accommodate the harder materials (they are more difficult to cut) associated with extended-burnup fue1. (6)

- Extending fuel burnup is a benefit in the criticality design of rod consolidation systems, wet and dry spent fuel storage systems, and shipping casks. (43)

- The impact on rod consolidation operations of further degradation of the mechanical and structyraj properties of extended-burnup fuel rods needs to be considered. (43)

- Increased radiation and heat sources produced in the fue 7 and the higher initial uranium-235 enrichment (affects criticality 
analyses) are the principal effects of extending fuel burnup on spent fuel storage systems. The increased heat and gamma radiation from such fuel can be accommodated by additional cooling time, but the increased neutron radiation (principal emitters are $242 \mathrm{Cm}$ and ${ }^{244} \mathrm{Cm}$ ) cannot be accommodated unless the balance of gamma and neutron contrjbutions to the overall dose rate is properly selected initially. (48) Hence, extending fuel burnup can potentially require some minor alterations in the designs of transport casks, storage systems, and fuel consolidation equipment. (43)

- Currently available transportation casks can carry extended burnup fuel at their design capacity, unless they are limited because of criticality concerns. (5)

\subsection{RECOMMENDATIONS}

Discussed in the following three subsections are the recommendations, based on the results and conclusions of this study, concerning a) the inventory of spent intact and defective (failed or damaged) LWR fuel assemblies that have attained extended burnup levels, b) the performance, integrity, and potential Timitations of extended-burnup fuel in reactors, and c) the effect of extended-burnup fuel on handling, interim storage, and other operations (e.g., rod consolidation and shipping).

\subsubsection{Experience Base with Extended-Burnup Fuel}

A recommendation concerning the U.S. inventory of LWR spent fuel in storage is as follows:

- Continue to assess the domestic inventory of spent fuel and identify (e.g., as under EPRI's "lead fuel as sembly concept") candidate lead fuel assemblies to aid in validating safe storage for bounding storage conditions. (49)

\subsubsection{Performance, Integrity, and Potential Limitations}

Recommendations regarding the performance, integrity, and potentia] limitations of extended-burnup fuel in reactors are listed below:

- For waste management planning and repository design, monitor the behavior of intact and defective (i.e., failed or damaged) higher burnup spent fuel that is placed in wet and dry storage to gain additional exjence that fuel integrity is being appropriately maintained. (3)

- Identify the root causes of fuel failures when they occur. (18) 
- Perform additional studies to improve the understanding of the impact of the observed pellet-rim porosity on the overall performance of extended-burnup fuel. (50) (At pellet-averaged burnups over about $40 \mathrm{GWd} / \mathrm{MTIHM}$, a porous rim formed at the pellet periphery; high local fission gas release fractions were noted in that region.)

- Monitor irradiation performance of extended-burnup fuel to predict the actual conditions and burnup levels at which certain parameters (e.g., Zircaloy growth, Zircaloy corrosion, internal rod pressure, effect of radiation on Zircaloy properties ${ }^{2}$ pellet-cladding interactions) are likely to become limiting. $(9,23)$

- Monitor important fuel behavior phenomena such as Zircaloy and structura] component corrosion to support further extension of fue 1 burnup. (51)

- Develop a cladding alloy material (Zircaloy and zirconium alloys) that is highly resistant to waterside corrosion under all BWR and PWR operating conditions. $(18,33)$

- Perform irradiation and corrosion tests on advanced cladding
designs to mitigate the concern about waterside corrosion. (22)

- Develop more test data to identify the separate contributions of irradiation damage and bydrogen pickup on the ductility of highly irradiated Zircaloy-4. (27)

- Recognize the effect of accelerated corrosion when considering even longer ffuel cycles and very high burnups. [A recent Westinghouse paper $(30)$ states that accelerated corrosion was observed in the last cycle (fifth) of exposure in the higher power regions of fuel that attained a burnup of 52,000 MWd/MT IHM.]

- Develop fuel design options for obtaining burnups of 40-45 GWd/MTIHM in BWRs and 55-60 GWd/MTIHM in PWRs (18)

\subsubsection{Effect on Operations}

Recommendations pertaining to the effect of extended-burnup fue 1 on handling, storage, and other operations (e.g., rod consolidation and shipping) subsequent to reactor service are listed below:

- Undertake further crud characterization studies to provide support for ongojing, handling facility designs and future licensing actions. (47) Emphasis should be placed on estimating fractional crud releases from spent fuel for various handling and transporting operations. 
- Develop an understanding of the effects of cleaning agents on subsequent fuel performance in the reactor and on fuel behavior in subsequent storage; there will grobably be a need to reirradiate some cleaned test assemblies. (18) Irradiation of some cleaned (decontaminated) BWR fuel components is planned under an EPRIsponsored program. $(52)$ 


\subsection{DISCUSSION}

The domestic inventory of LWR spent fuel and the experience base with extended-burnup fuel is discussed below in Section 3.1. The performance, integrity, and potential limitations of extended-burnup fuel are described below in Section 3.2. The effect of extended-burnup fuel on handling, storage, and other operations (e.g., rod consolidation, shipping) is discussed below in Section 3.3.

\subsection{EXPERIENCE BASE WITH EXTENDED-BURNUP FUEL}

The fuel vendors that provide LWR fuel for domestic plants indicate that as of the end of 1986, over 109,615 fuel assemblies were in or had completed operation in U.S. and other commercial plants (see Table 3.1). ${ }^{(53)}$ Those assembiies contain over 12.2 million fuel rods. Estimates of the number of extended-burnup fuel assemblies and the number of failed or damaged extendedburnup fuel assemblies currently in domestic storage are provided below in Sections 3.1.1 and 3.1.2, respectively. Projections of the future use of extended-burnup fuel are described below in Section 3.1.3.

\subsubsection{Estimated Number of Extended-Burnup Fuel Assemblies Currently in Storage}

Based on information supplied by utilities to DOE's Energy Information Administration (EIA), 50,921 fuel assemblies(a) are currently in storage in domestic facilities (Table 3.2). Of those 50,921 fue 7 assemblies, over $97 \%$ contain Zircaloy-clad fuel rods and nearly $3 \%$ contain stainless steel-clad fuel rods. Of the 50,921 fuel assemblies, $16.8 \%$ have burnups of 30,000 to $<35,000 \mathrm{MHd} / \mathrm{MT}$ IHM, (b) $4.9 \%$ have burnups of 35,000 to $<40,000 \mathrm{MWD} / \mathrm{MTIHM}, 0.4 \%$ have burnups of 40,000 to $<45,000 \mathrm{MWd} / \mathrm{MTIHM}, 0.01 \%$ have burnups of 45,000 to $<50,000 \mathrm{MWd} / \mathrm{MTIHM}$, and $0.02 \%$ have burnups of 50,000 to $<55,000 \mathrm{MWd} / \mathrm{MTIHM}$.

\footnotetext{
(a) The terms "fuel assembly" and "fuel bundle" are used interchangeably in the nuclear industry, al though generally the former term is associated with fuel for PWRs and the latter with fuel for BWRs. A BWR fuel assembly consists of a fuel bundle and an open-ended channel that encloses the bundle.

(b) Megawatt-days per metric ton of initial heavy metal (MWd/MTIHM).
} 
IABLE 3.1. Cumulative Number (through December 31, 1986) of BWR and PWR Fuel Assemblies and Fuel Rods that Haxe Been 1rradiated and Discharged and that Are Currently Being Irradiated $(28,53)$

Fuel Vendor

Advanced Nuclear Fuels Corporation (formerly Exxon Nuclear Company, Inc.)

Babcock \& Wilcox

Company

is

Inc.

\begin{tabular}{ccc} 
Number of Fuel Assemblies \\
\hline $\begin{array}{c}\text { Zircaloy- } \\
\text { Clarcaloy- }\end{array}$ & Stainless \\
Clad & Steel-Clad \\
BWR Fuel PWR Fuel PWR Fuel
\end{tabular}

5,732

4,927
4,594

5,971

$>66,800(\mathrm{a})$

\begin{tabular}{|c|c|c|}
\hline & 21,123 & \\
\hline$>72,532$ & 36,615 & 468 \\
\hline
\end{tabular}

$\begin{aligned}>72,532 & \text { BWR Fuel Assemblies } \\ 37,083 & \text { PWR Fuel Assemb } 1 \text { ies (b) } \\ >109,615 & \text { Fuel Assemblies }(d)\end{aligned}$
Number of Fuel Rods

\begin{tabular}{ccc}
$\begin{array}{c}\text { Zircaloy- } \\
\text { Clad } \\
\text { BWR Fuel }\end{array}$ & $\begin{array}{c}\text { Zircaloy- } \\
\text { Clad } \\
\text { PWR Fuel }\end{array}$ & $\begin{array}{c}\text { Stainless } \\
\text { Steel-Clad } \\
\text { PWR Fuel }\end{array}$ \\
\cline { 1 - 1 } 365,119 & & $1,024,819$
\end{tabular}

General Electric

Westinghouse Electric Corporation

SUBTOTALS

\begin{tabular}{|c|c|c|c|}
\hline$>72,532$ & 36,615 & $>4,195,119$ & $7,972,748$ \\
\hline $\begin{array}{r}>72,532 \\
\quad 37,083 \\
>109,615\end{array}$ & $\begin{array}{l}\text { BWR Fuel Assemblies } \\
\text { PWR Fuel Assemb } 1 \text { jes (b) } \\
\text { Fuel Assemblies }(d)\end{array}$ & $\begin{array}{r}>4,195,119 \\
8,068,220 \\
>12,263,339\end{array}$ & $\begin{array}{l}\text { BWR Fuel Rods } \\
\text { PWR Fuel Rods (c) } \\
\text { Fuel Rods }(\mathrm{e})\end{array}$ \\
\hline
\end{tabular}

\footnotetext{
(a) As of January 1987 .

(b) Of which $98.74 \%$ contain Zircaloy-clad fuel and $1.26 \%$ contain stainless-steel-clad fuel.

(c) Of which $98.82 \%$ have Zircaloy cladding and $1.18 \%$ have stainless steel cladding.

(d) of which $>99.52 \%$ contain Zircaloy-clad fuel and $<0.48 \%$ contain stainless-steel-clad fuel.

(e) of which $\sim 99.22 \%$ have Zircaloy cladding and $\sim 0.78 \%$ have stainless steel cladding.
} 
TABLE 3.2. Burnup Ranges for Permanentiy Discharged BWR and PWR Spent Fuel in Storage at Domestic Sites(a)

- Zircaloy-Clad Fuel

Burnup, MWd/MTIHM (b) No. of Fuel Assemblies

55,000 and higher 50,000 and higher 45,000 and higher 40,000 and higher 35,000 and higher 30,000 and higher 25,000 and higher 0 and higher

\begin{tabular}{r}
\hline BWR \\
\hline 0 \\
0 \\
0 \\
5 \\
12 \\
1,723 \\
10,486 \\
30,350
\end{tabular}

- Stainless Steel-Clad Fuel $(c, d)$

\begin{tabular}{rr} 
PWR & \multicolumn{1}{r}{ Total } \\
0 & 0 \\
9 & 9 \\
14 & 14 \\
199 & 204 \\
2,577 & 2,589 \\
8,817 & 10,540 \\
14,010 & 24,496 \\
19,057 & 49,407
\end{tabular}

\begin{tabular}{rrr}
\multicolumn{3}{c}{ MTIHM } \\
BWR & PWR & Total \\
\cline { 1 - 1 } 0 & 0 & 0 \\
0 & 4 & 4 \\
0 & 6 & 6 \\
1 & 82 & 83 \\
2 & 1,070 & 1,073 \\
311 & 3,776 & 4,088 \\
1,917 & 5,963 & 7,879 \\
5,553 & 8,158 & 13,691
\end{tabular}

- Stainless steel-Clad Fuel

Burnup. MWd/MTIHM

55,000 and higher 50,000 and higher 45,000 and higher 40,000 and higher 35,000 and higher 30,000 and higher 25,000 and higher 0 and higher

\begin{tabular}{rrr} 
No. of Fuel Assemblies \\
\hline BWR & \multicolumn{1}{c}{ PWR } & Total \\
0 & 0 & 0 \\
0 & 0 & 0 \\
0 & 0 & 0 \\
0 & 0 & 0 \\
0 & 109 & 109 \\
0 & 690 & 690 \\
0 & 1,009 & 1,009 \\
261 & 1,253 & 1,514
\end{tabular}

\begin{tabular}{crr}
\multicolumn{3}{c}{ MTIHM } \\
BWR & PWR & Total \\
0 & 0 & 0 \\
0 & 0 & 0 \\
0 & 0 & 0 \\
0 & 0 & 0 \\
0 & 45 & 45 \\
0 & 276 & 276 \\
0 & 391 & 391 \\
30 & 463 & 493
\end{tabular}

- Total Quantity of Fuel

\begin{tabular}{|c|c|c|c|c|c|c|}
\hline \multirow[b]{2}{*}{ Burnup, MWd/MTIHM } & \multicolumn{3}{|c|}{ No. of Fuel Assemblies } & \multicolumn{3}{|c|}{ MTIHM } \\
\hline & BWR & PWR & Total & BWR & PWR & Total \\
\hline $\begin{array}{l}0 \text { and higher } \\
0 \text { and higher } \\
0 \text { and higher } \\
0 \text { and higher } \\
0 \text { and higher } \\
10 \text { and higher } \\
10 \text { and higher } \\
\text { and higher }\end{array}$ & $\begin{array}{r}0 \\
0 \\
0 \\
5 \\
12 \\
1,723 \\
10,486 \\
30,611\end{array}$ & $\begin{array}{r}14 \\
199 \\
2,686 \\
9,507 \\
15,019 \\
20,310\end{array}$ & $\begin{array}{r}14 \\
204 \\
2,698 \\
11,230 \\
25,505 \\
50,921\end{array}$ & $\begin{array}{r}0 \\
1 \\
2 \\
311 \\
1,917 \\
5,563\end{array}$ & $\begin{array}{r}0 \\
4 \\
6 \\
82 \\
1,115 \\
4,053 \\
6,354 \\
8,621\end{array}$ & $\begin{array}{r}0 \\
4 \\
6 \\
83 \\
1,117 \\
4,364 \\
8,271 \\
14,184\end{array}$ \\
\hline
\end{tabular}

(a) Source: CY-1986 Nuclear fueT Data Form RW-859 from DOE's Energy Information Administration.

(b) Megawatt-days per metric ton of initial heavy metal (MWd/MTIHM).

(c) Involves fuel from these reactors: Haddam Neck (also known as Connecticut Yankee), Indian Point-1, La Crosse, and San Onofre. La Crosse is a BWR; the others are PWRs.

(d) Approximately 40 fuel assemblies (11 MT) of stainless steel-clad fuel remain at Yankee Rowe (PWR), but cannot be differentiated with the data that are available. That fuel is included with the Zircaloy-clad fuel above. 
U.S. experience with extended-burnup fuel rods is 1 isted in Table 3.3, which shows that over 63,300 LWR fuel rods have attained burnups of 40,000 MWd/MTIHM or higher. The BWR and PWR spent fuel assemblies with the highest burnups that were permanently discharged during each year from 1971 through 1986 are listed in Tables 3.4 and 3.5, respectively. The weighted average burnups of all BWR and PWR spent fuel assemblies that were permanentiy discharged during the period 1971 through 1986 are provided in Table 3.6.

\subsubsection{Estimated Number of Failed or Damaged Extended-Burnup Fuel Assemblies Currently in Storage}

The number of failed fuel assemblies and damaged fuel assemblies (i.e., ones that sustained mechanical or chemical damage but with fuel cladding that is not breached) that are currently among the $-51,000$ fuel assemblies (Table 3.2) in storage in the United States was estimated in a recent PNL

\section{TABLE 3.3. U.S. Experience with Extended-Burnup Fuel Rods ${ }^{(53)}$}

\section{- BWR Fuel}

\begin{tabular}{|c|c|}
\hline $\begin{array}{l}\text { No. of } \\
\text { Fuel Rods }\end{array}$ & Burnup, MWd/MTIHM (a) \\
\hline over 6,000 & $36,000^{(b)}$ \\
\hline over & 40,000 to $42,000^{(c)}$ \\
\hline
\end{tabular}

- PWR Fuel

No. of Fuel

Fuel Rods

over 374,198

$$
\begin{array}{r}
62,992^{(d)} \\
2,239^{(e)} \\
1,256^{(f)}
\end{array}
$$

Burnup. MWd/MTIHM

36,000 and higher 40,000 and higher 48,000 and higher 52,000 and higher

(a) Megawatt-days per metric ton of initial heavy meta T (MWd/MTIHM).

(b) Batch average.

(c) Rod average.

(d) Of the 374,198 rods.

(e) of the 62,992 rods

(f) Of the 2,239 rods. 
IABLE 3.4. Permanently Discharged BWR Spent Fue1 With the Highest Average Burnup (a)

\begin{tabular}{|c|c|c|c|c|}
\hline $\begin{array}{l}\text { Year of } \\
\text { Discharge }\end{array}$ & $\begin{array}{l}\text { Month When } \\
\text { Discharged }\end{array}$ & $\begin{array}{l}\text { Average Burnup, } \\
\text { MWd/MTIHM (b) }\end{array}$ & $\begin{array}{l}\text { No. of Fuel } \\
\text { Assemblies }\end{array}$ & Reactor \\
\hline $\begin{array}{l}1968 \\
1969\end{array}$ & $\begin{array}{l}\text { June } \\
\text { September }\end{array}$ & $\begin{array}{r}1,874 \\
25,2 B 7\end{array}$ & $\begin{array}{l}1 \\
1\end{array}$ & $\begin{array}{l}\text { Big Rock Point } \\
\text { Dresden-1 }\end{array}$ \\
\hline $\begin{array}{l}1970 \\
1971\end{array}$ & September & $\begin{array}{c}\text { BWR discharge } \\
24,902\end{array}$ & his year-- & Dresden-1 \\
\hline & & & $\begin{array}{l}2 \\
1\end{array}$ & $\begin{array}{l}\text { Big Rock Point } \\
\text { Dresden-1 }\end{array}$ \\
\hline 1974 & Augu & 27 , & 1 & Dresden-1 \\
\hline 1975 & Sept & & 17 & $\begin{array}{l}\text { Oresouen-1 } \\
\text { Dressen-? }\end{array}$ \\
\hline $\begin{array}{l}1976 \\
1977\end{array}$ & $\begin{array}{l}\text { March } \\
\text { April }\end{array}$ & & $\begin{array}{l}1 \\
4\end{array}$ & $\begin{array}{l}\text { Dresden-2 } \\
\text { Oyster Creek }\end{array}$ \\
\hline $\begin{array}{l}1978 \\
1979\end{array}$ & $\begin{array}{l}\text { September } \\
\text { February }\end{array}$ & & $\begin{array}{r}84 \\
2\end{array}$ & $\begin{array}{l}\text { Oyster Creek } \\
\text { Big Rock Point }\end{array}$ \\
\hline 1980 & Febrt & & 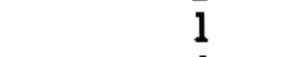 & Monticello \\
\hline 1981 & March & & 4 & $\begin{array}{l}\text { Monticello } \\
\text { Monticello }\end{array}$ \\
\hline $\begin{array}{l}1982 \\
1983\end{array}$ & $\begin{array}{l}\text { September } \\
\text { February }\end{array}$ & & $\begin{array}{l}2 \\
4\end{array}$ & $\begin{array}{l}\text { Mont icello } \\
\text { Oyster Creek }\end{array}$ \\
\hline 1984 & April & & 0 & Peach Bottom-2 \\
\hline 1985 & & & & Peach Bottom-3 \\
\hline & & & 92 & Dresden-2 \\
\hline & tember & & 2 & Cities \\
\hline
\end{tabular}

(a) Source: CY-1987 Nuclear Fuel Data Form RW-859 from DOE's Energy Information Administration. DOE/RL-88-34, October 1988.

(b) Megawatt-days per metric ton of initial heavy metal (MWd/MTIHM).

report, PNL-5882. ${ }^{(3)}$ The defective (i.e., failed or damaged) fuel assemblies were also categorized in that report. There are two important points to keep in mind regarding the estimates of the number of defective fuel assemblies. First, we are dealing with an incomplete data set. There are over 100 power reactors licensed for commercial operation in the United States, but only slightly over haTf have provided data to DOE's EIA on the number of defective fuel assemblies in storage. Secondly, evaluating data on defective fuel reported by industry is difficult for several reasons: 1) the definition of failed fuel can vary from outage to outage and from reload to reload for each utility, 2) the definition of abnormal degradation is not uniform throughout 
IABLE 3.5. Permanently Discharged PWR Spent Fuel with the Highest Average Burnup (a)

\begin{tabular}{|c|c|c|c|c|}
\hline $\begin{array}{c}\text { Year of } \\
\text { Discharge }\end{array}$ & $\begin{array}{l}\text { Month When } \\
\text { Discharged }\end{array}$ & $\begin{array}{l}\text { Average Burnup, } \\
\text { MWd/MTIHM (b) }\end{array}$ & $\begin{array}{l}\text { No. of Fuel } \\
\text { As semblies }\end{array}$ & Reactor \\
\hline $\begin{array}{l}1970 \\
1971 \\
1972 \\
1973 \\
1974 \\
1975 \\
1976 \\
1977 \\
1978 \\
1979 \\
1980 \\
1981 \\
1982 \\
1983 \\
1984 \\
1985 \\
1986 \\
1987\end{array}$ & $\begin{array}{l}\text { Apri1 } \\
\text { Apri1 } \\
\text { June } \\
\text { February } \\
\text { May } \\
\text { May } \\
\text { September } \\
\text { October } \\
\text { November } \\
\text { November } \\
\text { January } \\
\text { February } \\
\text { February } \\
\text { June } \\
\text { March } \\
\text { October } \\
\text { October } \\
\text { October }\end{array}$ & $\begin{array}{l}19,213 \\
27,213 \\
32,809 \\
32,804 \\
30,482 \\
32,833 \\
32,849 \\
36,713 \\
40,200 \\
40,007 \\
44,438 \\
42,764 \\
54,965 \\
50,598 \\
42,087 \\
47,932 \\
53,000 \\
44,000\end{array}$ & $\begin{array}{r}2 \\
2 \\
5 \\
1 \\
2 \\
48 \\
8 \\
1 \\
1 \\
1 \\
1 \\
1 \\
4 \\
1 \\
4 \\
1 \\
1 \\
1\end{array}$ & $\begin{array}{l}\text { Haddam Neck }(c) \\
\text { Haddam Neck } \\
\text { Haddam Neck } \\
\text { San Onofre-1 } \\
\text { Yankee Rowe } \\
\text { Haddam Neck } \\
\text { San Onofre-1 } \\
\text { Haddam Neck } \\
\text { Prairie Is I and-2 } \\
\text { Oconee-1 } \\
\text { Prairie Is I and-2 } \\
\text { Prairie Is I and-2 } \\
\text { Zion-1 } \\
\text { Oconee-1 } \\
\text { Cook-2 } \\
\text { Point Beach-2 } \\
\text { Farley-1 } \\
\text { Salem-1 }\end{array}$ \\
\hline
\end{tabular}

(a) Source: CY-1987 Nuclear Fuel Data Form RW-859 from DOE's Energy

Information Administration. DOE/RL-88-34, October 1988 .

(b) Megawatt-days per metric ton of initial heavy metal (MWd/MTIHM).

(c) Also known as Connecticut Yankee.

industry, 3) in many cases the number of fuel failures is inferred from indirect evidence, 4) in some cases only directly observed failures are counted, and 5) whether fuel is determined to be failed can depend on how closely the fuel is inspected and on the capability of the inspection technique being used [it can also depend on when an inspection such as sipping (leak testing) takes place]. ${ }^{(53-56)}$

The difficulty in interpreting data from ultrasonic testing of spent fue 1 assemblies to detect leaking fuel rods under certain situations (especially with high-burnup fuel or fuel that has thick crud deposits) is discussed 

TABLE 3.6. Weighted Average Burnyg for Permanently
Discharged Spent Fuel

\begin{tabular}{c}
$\begin{array}{c}\text { Year of } \\
\text { Discharge }\end{array}$ \\
\hline 1971 \\
1972 \\
1973 \\
1974 \\
1975 \\
1976 \\
1977 \\
1978 \\
1979 \\
1980 \\
1981 \\
1982 \\
1983 \\
1994 \\
1985 \\
1986 \\
1987
\end{tabular}

Weighted Average Burnup, MWD/MTIHM (b)

BWR Fuel PWR Fuel

$5,777 \quad 23,016$

$6,853 \quad 22,384$

$12,557 \quad 23,679$

$12,806 \quad 18,825$

$17,433 \quad 18,123$

$13,980 \quad 22,234$

$16, \mathrm{~B} 42 \quad 25,273$

$20,141 \quad 26,396$

$22,506 \quad 27,056$

$22,527 \quad 29,672$

$24,112 \quad 30,241$

$24,789 \quad 29,471$

$27,108 \quad 30,063$

$26,932 \quad 29,503$

$23,620 \quad 31,758$

$21,041 \quad 30,275$

$21,393 \quad 30,793$

(a) Source: CY-1987 NucTear Fue T Data Form RW-859 from DOE's Energy Information

Administration. DOE/RL-88-34, October 1988.

(b) Megawatt-days per metric ton of initial heavy meta] (MWd/MTIHM).

in a recent paper. ${ }^{(56)}$ Visual inspection, ultrasonic testing, and eddy current testing were all recently employed in examining fuel for a utility; results of the work indicate that if only one or two of the inspection methods had been used, it is entirely possible that one or more leakers and/or incipient failures could have been overlooked. ${ }^{(17)}$ An ultrasonic technique for inspecting BWR fuel bundles--without removing the channel--for leaking fuel rods is being developed. ${ }^{(57)}$ 
It is estimated that among the 50,921 fuel assemblies currently in storage, there are about 2300 defective (i.e., failed or damaged) fuel assemblies. (3) of those defective fuel assemblies, the largest number of defective BWR fuel assemblies (630) occurred in the 10,000 to 15,000 MWD/MTIHM burnup range, and the largest number of defective PWR fuel assemblies (100) occurred in the 35,000 to $30,000 \mathrm{MWd} / \mathrm{MTIHM}$ burnup range. In general, most of the defective BWR fuel assemblies have lower burnups and tend to be older than most of the defective PWR fuel assemblies. Of the 2300 defective fuel assemblies, over half the ones from BWRs have burnups in the 10,000 to 20,000 MWd/MTIHM range and occurred in the 1973-1975 period (the largest number, 493, occurred in 1974) and over half the ones from PWRs have burnups in the 20,000 to 35,000 MWd/MTIHM range and occurred in the 1979-1984 period (the largest number, 78, occurred in 1983). As indicated in Table 3.7, among those -2300 defective fuel assemblies are 411 fuel assemblies (43\% BWR, 57\% PWR) with burnups in the 25,000 to $45,000 \mathrm{MWd} / \mathrm{MTIHM}$ range.

\subsubsection{Projections of Future Use of Extended-Burnup Fuel}

A paper by DOE $^{(4)}$ published in 1987 indicates that implementation of burnup extension by utilities is proceeding in a step-wise fashion, with the highest PWR discharge batch burnups al ready achieved exceeding

TABLE 3.7. Burnup 0istribution for Defective U.S. Fuel Assemblies with Burnups of 25,000 MWd/MTIHM(a) or Higher (b)

Range of Burnup, No. of BWR Fuel No. of PWR Fuel No. of BWR and PWR Fuel

MWd/MTIHM

25,000 to 30,000

30,000 to 35,000

35,000 to 40,000

40,000 to 45,000 Assemblies

120

58

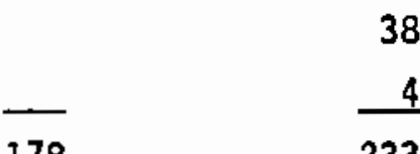
Assemblies
220

149

38

38

4

4

411

(a) Megawatt-days per metric ton of initial heavy metal (MWd/MTIHM).

(b) Source: CY-1987 utility data base information on fuel (j.e., CY-1987 Nuclear Fue] Data Form RW-859) supplied to DOE's Energy Information Administration. DOE/RL-88-34, September 1988. 
40,000 MWd/MTIHM and the highest anticipated burnups for fuel already ordered or loaded being 45,000 MWd/MTIHM. As noted in the paper, these represent the most ambitious cases. Batch average burnups of about $45 \mathrm{GWd} / \mathrm{MTIHM}$ and about 60 GWd/MTIHM for BWRs and PWRs, respectiveTy, are expected in the 1990s. (19) It takes five to six years to attain burnups of 50 to $60 \mathrm{GWd} / \mathrm{MTIHM}$, respectively, in a PWR. ${ }^{(9)}$ Batch-average burnups at Babcock \& Wilcox Company (B\&W) piants have been recently rising at the rate of $1.3 \mathrm{GWd} /$ MTIHM per cycle. (26) More moderate extension of burnup is very widespread, with over $80 \%$ of the LWRs in the United States extending burnup by at least $10 \%$ over the traditional values of the 1970 s or having made the decision to do so in immediate future cycles. $(4,5)$ That trend is anticipated to continue; extensions of about $35 \%$ have been shown to be reasonably achievable. ${ }^{(5)}$ An estimate of the quantities of spent fuel by age in 1990 and the associated discharge exposure is shown in Table 3.8 .

It is indicated in a 1988 paper ${ }^{(18)}$ that for 1990 and beyond, the initial driving force in the U.S. for developing higher-burnup fuel design will be to reduce the requirements for on-site storage of spent fuel and for fuel consolidation and that, eventually, resolution of fuel cycle closure may have an effect. Fuels designed for high burnup help relieve the throughput into the spent fuel storage pools and facilitate longer operating cycles, but they most assuredly do not lower fuel cost significantly.

\subsection{PERFORMANCE, INTEGRITY, AND POTENTIAL LIMITATIONS OF EXTENDED-BURNUP FUEL}

Extensive research and development has been directed toward extending fuel burnup while assuring fuel reliability and the programs are reaching fruition. Burnups have been increased by almost $50 \%$ over the limits used less than a decade ago. ${ }^{(59)}$ Fuel has shown excellent reliability and the trend is expected to continue. ${ }^{(59)}$ Fuel reliability is one of the overall performance indicators adopted by the Institute of Nuclear Power Operations (INPO) for the industry-wide nuclear power plant performance indicator program that was initiated in $1981{ }^{(60)}$ 
TABLE 3.8. Quantities of Spent Fuel by Age in 1990 and Discharge Exposure(a)

Number of Fuel Assemblies

\begin{tabular}{|c|c|c|c|c|c|c|c|}
\hline \multirow[b]{3}{*}{$\begin{array}{l}\text { Age, } \\
\text { Years }\end{array}$} & \multirow[b]{3}{*}{$\begin{array}{l}\text { Year(s) When Fuel } \\
\text { Was Discharged }\end{array}$} & \multicolumn{6}{|c|}{ Number of Fuel Assemblies } \\
\hline & & \multicolumn{5}{|c|}{ Discharge Exposure, MWd/MTIHM (b) } & \multirow{2}{*}{$\begin{array}{l}\text { Total No. } \\
\text { of Fuel } \\
\text { Assemblies }\end{array}$} \\
\hline & & $\begin{array}{c}0 \text { to } \\
10,000\end{array}$ & $\begin{array}{l}\text { Over } 10,000 \\
\text { to } 20,000 \\
\end{array}$ & $\begin{array}{l}\text { Over } 20,000 \\
\text { to } 30,000 \\
\end{array}$ & $\begin{array}{l}\text { Over } 30,000 \\
\text { to } 40,000 \\
\end{array}$ & $\begin{array}{r}\text { Over } \\
40.000 \\
\end{array}$ & \\
\hline $0-3$ & $1987-1990$ & 271 & 966 & 2,447 & 4,147 & 610 & 8,441 \\
\hline $4-5$ & $1985-1986$ & 124 & 385 & 1,042 & 1,294 & 62 & 2,907 \\
\hline $6-10$ & $1980-1984$ & 31 & 476 & 3,182 & 2,287 & 19 & 5,995 \\
\hline \multirow[t]{2}{*}{$11-22$} & $1968-1979$ & $\underline{467}$ & $\underline{2,097}$ & 2.050 & 676 & 1 & 5,291 \\
\hline & Totals & 893 & 3,924 & 8,721 & 8,404 & 692 & 22,634 \\
\hline
\end{tabular}

(a) Source: CY-1986 utility data base information on fuel discharges through 1990 (i.e., CY-1986 Nuclear Fuel Data Form RW-859) supplied to DOE's Energy Information Administration.

(b) Megawatt-days per metric ton of initial heavy metal (MWd/MTIHM). 
Typical initial goals for DOE's aggressive development programs to increase burnup (initiated in 1978) were to achieve discharge batch average burnups of 45,000 MWd/MTIHM for BWRs and 50,000 MWd/MTIHM for PWRs. (4) The corresponding peak rod average burnups were 50,000-55,000 MWd/MTIHM for BWRs and 55,000-60,000 MWd/MTIHM for PWRs. A 1987 report ${ }^{(61)}$ indicates that a new goal by the Electric Power Research Institute (EPRI) in the United States is to achieve a fuel reliability of $99.99 \%$ by 1990 with a fuel burnup of 60,000 MWd/MTIHM by 1997. In general, the overall domestic fuel operating experience continues to be excellent: current fuel rod reliabilities are typically $>99.99 \%$, which corresponds to fuel rod failure rates of $<0.01 \%$. (3) The performance and integrity of extended-burnup fuel at present are described below in Section 3.2.1. The potential limitations of extendedburnup fuel are discussed below in Section 3.2.2.

\subsubsection{Performance and Integrity of Extended-Burnup Fuel}

Good performance of LWR fuel irradiated to high burnup has been reported in documentation by many authors, including those listed in Table 3.9. The technical issues requiring consideration and resolution for extending fue] burnup have been enumerated eartier by a number of investigators. ${ }^{(4,8-10,16,18,27,30-33,40-42,50,62-64)}$ Performance considerations for LWR fuel assemblies for extended burnup are listed in Table 3.10. ${ }^{(63)}$ Table 3.11 shows the fuel parameters that are affected by extending burnup and the approximate order of importance of those parameters.

Average burnup levels have been increasing yearly, but fuel rod failure rates have not exhibited a similar trend; information published in 1985 indicates that extending burnup levels has not had an obvious detrimental effect on fuel performance. $(20,21)$ The fully successful results from DOE programs to increase fuel burnup are described in a 1987 paper. ${ }^{(4)}$ The programs involved fuel of both traditional and advanced designs. It is noted in the paper $^{(4)}$ that no significant unexpected phenomena or trends that would 1 imit burnup to lower levels have been encountered in the burnup ranges studied. Also, good design and licensing data, which are of benefit to the nuclear industry, have been obtained on fuel that has been irradiated to high burnup levels. 
TABLE 3.9. LWR Fuel Irradiated to Extended-Burnup Leve1s

Burnup, MHd/MTIHM (a)

- Fuel Assembly or Fuel Rod Burnups:

$$
\begin{aligned}
& >30,000 \text { to } \leq 35,000 \\
& >35,000 \text { to } \leq 40,000 \\
& >40,000 \text { to } \leq 45,000 \\
& >45,000 \text { to } \leq 50,000 \\
& >50,000 \text { to } \leq 55,000 \\
& >55,000 \text { to } \leq 60,000 \\
& >60,000 \text { to } \leq 65,000
\end{aligned}
$$

$$
\begin{aligned}
& 9,51,65-69 \\
& 8,16,19,22,25,31,51,70-74 \\
& 7,8,16,18,25,27,28,30,31,33,37,51, \\
& 67,70,74-81 \\
& 4,9,16,18,22,25,26,41,50,62,67,70 \\
& 73,74 \\
& 7,9,16,27,35,51,62,71,73,74,79,81,82 \\
& 9,16,27,34,50,62,68,74,81,83,84 \\
& 16
\end{aligned}
$$

- Peak Pellet Burnups:

$\begin{array}{ll}64,000 & 41,73 \\ 68,000 & 32 \\ 71,000 & 85 \\ 72,000 & 82 \\ 74,000 & 16 \\ 80,000 & 80\end{array}$

(a) Megawatt-days per metric ton of initial heavy metal.

of fuel designed specifically for extended burnup, the only known occurrence in the United States of failure of such fuel operating in the extended burnup range took $p l$ ace in a core having many debris-induced failures of traditional fuel. (4) During the past several years, about one-half of the total number of PWR fuel rods damaged have been the result of externally induced causes, including debris in the reactor coolant and baffle jetting. (86) Westinghouse Electric Corporation is developing and testing a debris filter for PWR fuel assemblies to trap particles that can lead to fuel damage through fretting. ${ }^{(23)}$ One debris-resistant fuel design by Advanced Nuclear Fuels Corporation (ANF) involves a solid Zircaloy lower end cap about 3 to $4 \mathrm{in}$. long to preclude penetration of the cladding by fretting from debris frequently trapped in this region of the fuel assembly. (25) 

IABLE 3.10. Performance Consiggrations for LWR Fuel Assemblies for

\begin{tabular}{|c|c|c|}
\hline Item & Consideration & Design/Performance Impact \\
\hline Pellet & Swelling & $\begin{array}{l}\text { Pellet swelling increases with burnup. } \\
\text { With cladding contact, this can result } \\
\text { in pellet-to-cladding bonding and } \\
\text { cladding tensile strain. }\end{array}$ \\
\hline Fission gas & Rod internal pressure & $\begin{array}{l}\text { Fission-gas release increases with } \\
\text { increasing burnup. This is acceptable } \\
\text { provided that the internal rod pres- } \\
\text { sure criteria are not exceeded. }\end{array}$ \\
\hline \multirow[t]{5}{*}{ Cladding } & Corrosion/oxidation & $\begin{array}{l}\text { It increases in an accelerating manner } \\
\text { with an increase in burnup because of } \\
\text { adverse effect on cladding tempera- } \\
\text { ture. }\end{array}$ \\
\hline & Hydriding & $\begin{array}{l}\text { It is of less concern than oxidation. } \\
\text { It reduces ductility. }\end{array}$ \\
\hline & Creep & $\begin{array}{l}\text { At high burnups, cladding could be in } \\
\text { tensile creep as a result of fuel } \\
\text { swelling and higher fission-gas } \\
\text { pressure. }\end{array}$ \\
\hline & Growth & $\begin{array}{l}\text { Cladding increases in length with } \\
\text { increasing burnup. Clearance is } \\
\text { required to prevent rod interference } \\
\text { with structural components. }\end{array}$ \\
\hline & Ductility & $\begin{array}{l}\text { Ductility decreases and yield stress } \\
\text { increases with increasing fast neutron } \\
\text { fluence. However, most property } \\
\text { changes occur very early during } \\
\text { irradiation, and the incremental } \\
\text { effect of higher burnups is not a } \\
\text { major concern. }\end{array}$ \\
\hline Fuel rod & Flattening & $\begin{array}{l}\text { Avoidance of rod flattening is a } \\
\text { licensing requirement. Adequate } \\
\text { prepressurization levels in fabri- } \\
\text { cation must be ensured. }\end{array}$ \\
\hline
\end{tabular}

(a) Departure from nucleate boiling (DNB). 
IABLE 3.10. (contd)

$\frac{\text { Item }}{\text { Fuel-rod bow }} \frac{\text { Consideration }}{\text { Impact DNB }}$

Fuel assembly guide tubes

Corrosion (hydriding)
Growth

Wear

Stress relaxation

Hydriding

Growth

\section{Design/Performance Impact}

This has an impact mainly during the second cycle of operation. For current fuel designs, rod bow is much reduced in frequency, magnitude, and potential impact on DNB margins.

The fuel assembiy Zircaloy guide tubes operate at lower temperature and with no heat flux compared to fuel rod tubes. Consequently, corrosion (oxidation) is not a major concern even though it is two sided. However, hydriding and subsequent loss of ambient ductility are considerations, because hydrogen uptake is occurring through both surfaces.

Growth of the guide thimbles (overall assembly growth) occurs during irradiation but is quite smal1. Higher burnups could cause increased deflection of the fuel assembly holddown spring.

Wear of the guide thimble caused by vibration of control-rod clusters engaged in the fuel assembiy has been previously observed. This is not burnup consideration per se.

The fuel rods are held in position by the spacer grid spring forces. Increased relaxation of these forces at high burnups may result in vibration of the fuel rods and fretting wear in the cladding at the point of relaxed spring contact.

For the Zircaloy springs, embrittlement from hydrogen uptake is an additional consideration for high burnup fuel.

For the Zircaloy straps in the spacer grids, growth will occur under irradiation. 
TABLE 3.11. Parameters Affected by Extending Fuel Burnup ${ }^{(9)}$

\begin{tabular}{lll} 
& \multicolumn{1}{c}{ Parameter } & $\begin{array}{c}\text { Approximate } \\
\text { Order of } \\
\text { Importance }\end{array}$ \\
\cline { 2 - 2 } $\begin{array}{l}\text { Parameters that are } \\
\text { more sensitive to } \\
\text { extended burnup }\end{array}$ & - Zircaloy Growth \\
$\begin{array}{l}\text { Parameters that are } \\
\text { Tess sensitive to } \\
\text { extended burnup }\end{array}$ & - Effect Cornal Pressure of Fuel Rods \\
- Properties & - Pellet-cladding interaction (PCI)
\end{tabular}

Though fuel reliability has improved substantially in recent years, the nuclear industry has indicated that even higher reliability is of major importance and will be needed in the future for a wide variety of operating conditions. (18) From the utilities' perspective, good fuel performance is not easily attained. (17) The utilities will be striving for fuel failure rates of less than one in $10^{5}$ rods (i.e., a reliability of $>99.999 \%$, which corresponds to a failure rate of $<0.001 \%$ ). According to a recent paper, (18) the pressure to continually improve fuel reliability will remain, in spite of further improvements, because of the importance of maintaining the integrity of the first barrier (the cladding) to the release of radioactive products to the reactor coolant and eventually to the environment. The failure rate of fuel rods is not anticipated to increase for extended-burnup fuel. ${ }^{(6,7)}$ To date, no evidence of a degradation in fuel performance or safety has been detected in extended burnup fuel operating experience with experimental and test fuel assemb]ies up to the current NRC-approved burnup levels (i.e., generic approvals for batch-average burnups of 35 to $40 \mathrm{GWd} / \mathrm{MTIHM}$ for BWRs and 40 to 45 GWd/MTIHM for PWRs).

The fuel vendors that provide the LWR fuel for domestic nuclear power plants have made substantial progress in extending fuel burnup. In a recent paper, ${ }^{(25)}$ ANF states that their data base for high-burnup designs supports batch discharge burnups of $40 \mathrm{GWd} / \mathrm{MTIHM}$ and $48 \mathrm{GWd} / \mathrm{MTIHM}$ in BWRs and PWRs, respectively. Batch-average discharge burnups for B\&W PWR fue 1 are now approaching $38 \mathrm{GWd} / \mathrm{MTIHM}$; two recent types of B\&W fuel are designed for 
assembly average burnups of 55 GWd/MTIHM. (26) Discharge exposures for Combustion Engineering, Inc., (C-E) PWR fuel have been in the 35 to 45 GWd/MTIHM range; a data base for design and operation of fuel to burnups in excess of $50 \mathrm{GWd} /$ MTIHM has been developed. (27) In a recent paper (28) by General Electric Company (GE), it is stated that they have not experienced any new or unique fuel failure mechanism that is related to burnup or associated with a burnup related failure threshold. New GE designs for extending burnup to $38 \mathrm{GWd} /$ MTIHM in BWR fuel involve longer residence times in the reactor; fuel rod reliabilities of $99.994 \%$ appear achievable. (29) An advanced $9 \times 9$ array fuel design for 8WRs is capable of higher burnup than $8 \times 8$ fuel because of the lower linear heat generation rate; a peak assembly discharge burnup of 45,000 MHd/MTIHM appears quite feasible. (87) Successful irradiation of four Westinghouse Electric Corporation PWR fuel assemblies to a burnup of $55 \mathrm{GWd} / \mathrm{MTIHM}$ provided the technical basis for extending the Optimized Fuel Assembly (OFA) demonstration irradiations through five operating cycles. (30) Well-characterized performance data from experimental and lead test assemblies that have recently attained high burnup (i.e., up to $60 \mathrm{GWd} /$ MTIHM), as well as more reliable data at intermediate burnup levels, have been incorporated into vendor fuel performance codes. (8)

A recent paper ${ }^{(32)}$ from Belgium indicates that the behavior of high burnup fuel is generally good and satisfactory but largely affected by the fuel rod design, the fabrication parameters, and the power history.

At present the nuclear industry in the U.S. is faced with very few major problems with fuel and, as a result, our attention is often directed toward less-frequent fuel failure/damage problems--and the industry has found that low-frequency fuel failures are often difficult to locate and identify by failure mechanism. (18)

The trend for most fuel rods is for the cladding to creep down continuously up to burnups of 30 to $50 \mathrm{GWd} /$ MTIHM (depending on the fuel type); if rods reach high burnup (over $50 \mathrm{GWd} /$ MTIHM) and operate at 1 inear heat generation rates around $30 \mathrm{~kW} / \mathrm{m}$ up to a burnup of $70 \mathrm{GWd} / \mathrm{MTIHM}$, then the fuel rod diameter strongly increases (due to fuel swelling) and becomes even larger than the initial rod diameter. (32) 
Results of power ramp (transient) studies ${ }^{(34)}$ in France indicate that no faiTure of fuel rods occurs at high burnups ( 29 to $59 \mathrm{GWd} /$ MTIHM) and high linear heat generation rates despite very high cladding strain (as high as $-0.19 \%$ ) caused by fue1 expansion, high release of fission gas, and oxide structure modifications.

It is indicated in a recent GE paper ${ }^{(67)}$ that two of the major causes of failure of BWR fuel rods--pellet-cladding interaction (PCI) and crud-inducedlocalized-corrosion (CILC)--have been eliminated in fuel that is currently being produced. (19) Barrier cladding was invented by GE as a material solution to the PCI failure problem; acceptance and performance of GE barrier has been excellent. (28) The zirconium liner has the ability to deform under stress even at quite high burnup without propagating the damage to the outer cladding. (65) Adequate performance of barrier fuel at high fluences is currently anticipated but has not yet been demonstrated. ${ }^{(33)}$ Variability in the resistance of Zircaloy cladding to nodular corrosion in BWRs is a major contributing factor to fuel failure due to CILC. ${ }^{(88)}$

It is stated in a recent Westinghouse Electric Corporation paper (51) that continued monitoring of important fuel behavior phenomena will be needed to support further extension of fuel burnup. Phenomena of concern include Zircaloy and structural component corrosion in PWRs.

Results of examinations of PWR fuel irradiated to rod-averaged burnups up to $56 \mathrm{GWd} /$ MTIHM reveal that an interaction layer (i.e., pellet-to-cladding bonding) has formed at the pellet-cladding interface at extended burnups. The increased fuel rod growth observed in some fuel rods at extended burnup is attributed to the interaction caused by the bond layers and subsequent swelling of the fuel. ${ }^{(83)}$ It was also found that the retained ductility of the cladding was low at room temperature. ${ }^{(83)}$

It is indicated in a B\&W paper ${ }^{(26)}$ that reducing the fuel rod internal pressure is the most immediate measure to increase burnup capability. The need for we11-characterized fuel performance data has been emphasized as a result of work to develop extended-burnup fuel; an important part of such data involves the release of fission gas during power transients late in life. ${ }^{(36)}$ A recent paper ${ }^{(68)}$ contains information on studies of six PWR fuel 
rods (average burnups ranged from 34,900 to 55,100 MWd/MTIHM) that exhibited unusual behavior in the release of fission gas and in fuel-cladding mechanical interaction.

Additional studies would lead to a better understanding of the impact of the observed pellet-rim porosity (at pellet-averaged burnups over about $40 \mathrm{GWd} / M T$ IHM, a porous rim formed at the pellet periphery) on the overall performance of extended-burnup fuel. ${ }^{(50)}$ High local fission-gas release fractions (averaged about 40\%) were noted in the porous rim region. The porous rim is the result of the higher local fission product inventory due to the increase in plutonium concentration near the pellet surface and the associated higher fission rate.

It is indicated in a recent paper(18) that the importance of plant operating environment, in particular water chemistry, on fuel performance has not been well established. Tighter water-chemistry specifications have not improved fuel reliability.

The impact of hydrogen injection in BWRs on fuel performance is not certain; however, results from initial studies indicate that fuel performance is expected to be acceptable. (18) Tests at Dresden-2 with fuel bundles that had one and two cycles of exposure under hydrogen water chemistry conditions(a) showed no significant differences in Zircaloy corrosion, hydriding, or fuel rod crud deposits when compared to fuel bundles exposed to normal water chemistry. (89)

From studies on modifications of water chemistry in PWRs, the experimental trends suggest a minimum of hydrogen concentration that should be avoided. ${ }^{(90)}$ Cladding integrity is the concern as the hydrogen is present to minimize the concentration of oxidizing species generated by radiolysis.

Lengthening the fuel cycles has not had a measurable influence on fuel performance. (18) To support the requirements of 24 -month cycles, C-E is currently licensing average fuel assembly and maximum fuel rod burnup limits of $50 \mathrm{GWd} / \mathrm{MTIHM}$ and $60 \mathrm{GWd} / \mathrm{MTIHM}$, respectively. ${ }^{(80)}$

(a) Hydrogen injection is employed to reduce the likelihood of stress corrosion cracking of stainless steel components. 
Based on results from some studies of load following on fuel performance, current fuel designs may be capable of load following without adverse effects on the performance, at least for current conditions. (18) up to now in Germany, no fuel damage has been observed that could be directly attributed to load-following operations. ${ }^{(91)}$ In France, most $p 1$ ants operate under load-following and frequency control conditions; no adverse effect on fuel behavior has been observed. ${ }^{(92)}$ Load-following experience in the U.S. is increasing but as yet is not widespread; that limited experience has not revealed any evidence that fuel or nonfuel component performance has been adversely affected. ${ }^{(93)}$

In the past, irradiated LWR fuel assemblies have been reconstituted (i.e., defective fuel rods have been replaced and the assembly returned to service) and it is expected that some extended-burnup fuel will al so be reconstituted. Excellent performance has been observed with 230 reconstituted assemblies (several rods have reached burnups up to $59 \mathrm{GWd} / \mathrm{MTIHM}$ ).

Two BWR fuel bundles that had been irradiated for three cycles in Quad Cities- 2 were decontaminated (one bundle with the CANDECON solvent and one bundle with the LOMI solvent) in the Quad Cities spent fuel pool. (52) Fuel rod failures did not occur as a result of the treatment; incomplete removal of fuel deposits was observed in the former case and apparently complete removal in the latter case. ${ }^{(52)}$ The bundles were shipped offsite for examination and when they were returned, grid spacer damage was detected on the LOMI-treated bundle and on an untreated control bundle; the damage was attributed to vibration during shipment. ${ }^{(52)}$ Some of the cleaned (decontaminated) fuel components are to be reirradiated.

Technical interest in mixed-oxide $\left(\mathrm{UO}_{2}-\mathrm{PuO}_{2}\right)$ cores will continue; however, use of mixed-oxide will remain uncertain for some time because of political and economic uncertainties. (18) The integrity of mixed-oxide fuel rods has always been found to be at least as good as that of $\mathrm{UO}_{2}$ fuel rods. (95) Mixed-oxide fuel has been successfully irradiated in PWRs to burnups beyond $53 \mathrm{GWd} / \mathrm{MTIHM}$. ${ }^{(41)}$ 


\subsubsection{Potential Limitations of Extended-Burnup Fuel}

It is difficult to predict the actual conditions and burnup levels at which certain parameters (e.g., Zircaloy growth, Zircaloy corrosion, internal rod pressure, effect of radiation on Zircaloy properties, and pellet-cladding interactions) are likely to become limiting; hence, the conditions and burnup levels must be determined by monitoring of extended burnup fue $1 .(9)$

Fuel design options for obtaining burnups of 40-45 GWd/MTIHM in BWRs and 55-60 GWd/MTIHM in PWRs need to be developed. (18) Improvements can still be made in fuel designs; however, manufacturing quality is not always consistent and as a result there can be unanticipated variations in fuel performance. (18) In the future, the nuclear industry needs to identify the root causes of fuel failures when they occur. (18)

The potential limitations for extended burnup of BWR and PWR fuel in domestic LWRs are shown in Tables 3.12 and 3.13, respectively. For most of the performance parameters, there currentiy exists a good data base for burnups up to 34 GWd/MTIHM and 47 GWd/MTIHM for BWR fuel and PWR fuel, respectively--the exception is Zircaloy growth. (9)

Growth rates of Zircaloy are not yet well characterized at high fluences. (33) The rate of the fuel assembly length change seems to increase at higher burnups. (41) In licensing fuel for extended burnup operation, it was found that some fuel designs lacked data on fuel-rod and fuel-assembly growth at extended burnups. ${ }^{(8)}$ A11 fuel design calculations must be rechecked as burnups increase; fuel rod elongation is one parameter that typicaliy needs to be adjusted to assure that the fuel assembly can accommodate the anticipated growth of the longest fuel rod. ${ }^{(33)}$ Bonding of the fuel to the Zircaloy cladding at high burnup enhances the fuel-rod axial growth rate (the cladding is forced to creep axialiy at a rate that is controlled by the swelling of the fuel pellets). (27) A large variability in the data on fuel-rod axial growth is observed at burnups higher than about 20 GWd/MTIHM. ${ }^{(31)}$ To date, no effect on rod growth from load following operation has been found. ${ }^{(31)}$ Examinations of PWR fuel irradiated to burnups up to $54 \mathrm{GWd}$ MTIHM show that the fuel rod growth and Zircaloy oxide film thickness were not 1 imitations for extended-burnup operation. 
IABLE 3.12. Summagy of Potential Limitations for Extended Burnup of BWR

\begin{tabular}{|c|c|c|c|c|}
\hline \multirow[b]{2}{*}{ Parameter } & \multicolumn{3}{|c|}{$\begin{array}{l}\text { Burnup Experience, } \\
\text { GWd/MTIHM (a) }\end{array}$} & \multirow[b]{2}{*}{ Remarks (b) } \\
\hline & \multirow[t]{2}{*}{$\begin{array}{l}\text { Fuel } \\
\text { Rod }\end{array}$} & $\begin{array}{c}\text { Fuel } \\
\text { Assembly }\end{array}$ & $\begin{array}{l}\text { Equivalent } \\
\text { Batch }^{\text {(b) }} \\
\end{array}$ & \\
\hline Zircaloy Growth & & 34 & 28.5 & $\begin{array}{l}\text { Limit for General Electric } \\
\text { BWR } / 6 \text { design. }\end{array}$ \\
\hline \multirow[t]{2}{*}{ Zircaloy Corrosion } & \multirow[t]{2}{*}{45} & & 34 & $\begin{array}{l}\text { No limit at this level. It } \\
\text { is est imated }(c) \text { that a batch } \\
\text { average burnup of } \\
45 \text { GWd/MTIHM may be achiev- } \\
\text { able. }\end{array}$ \\
\hline & & & $(\geq 34)$ & $\begin{array}{l}\text { Heat treated cladding is } \\
\text { expected to have higher } \\
\text { limits. }\end{array}$ \\
\hline \multirow[t]{2}{*}{$\begin{array}{l}\text { Internal Fuel Rod } \\
\text { Pressure }\end{array}$} & \multirow[t]{2}{*}{45} & & 34 & $\begin{array}{l}\text { Data on unprepressurized } \\
\text { fuel. }\end{array}$ \\
\hline & & & $(\geq 34)$ & $\begin{array}{l}\text { Value for General Electric } \\
\text { fuel (design) is higher. The } \\
\text { limit is unknown. }\end{array}$ \\
\hline \multirow[t]{3}{*}{$\begin{array}{l}\text { Pellet-Cladding } \\
\text { Interaction in } \\
\text { Ramp Tests }\end{array}$} & 33 & & 25 & $\begin{array}{l}\text { Unprepressurized standard } \\
\text { fuel. Poor performance at } \\
\text { standard PCIOMRs. (d) }\end{array}$ \\
\hline & \multirow[t]{2}{*}{24} & & 18 & $\begin{array}{l}\text { Unprepressurized and prepres- } \\
\text { surized Zr barrier fuel. } \\
\text { Good performance has been } \\
\text { experienced. }\end{array}$ \\
\hline & & & $(\geq 34)$ & $\begin{array}{l}\text { (Design). Performance of } \\
\text { advanced BWR fuels expected } \\
\text { to be good. High burnup } \\
\text { achievable with operating } \\
\text { restrictions if that becomes } \\
\text { necessary. }\end{array}$ \\
\hline $\begin{array}{l}\text { Zircaloy } \\
\text { Properties }\end{array}$ & 42 & & 32 & $\begin{array}{l}\text { No limit at this level. It } \\
\text { is estimated }(c) \text { that higher } \\
\text { levels are achievable, but } \\
\text { are dependent on rate of } \\
\text { further ductility loss with } \\
\text { burnup. }\end{array}$ \\
\hline
\end{tabular}


TABLE 3.12. (contd)

Burnup Experience, GWd/MTIHM (a)

Fuel Fuel Equivalent

Parameter

Spring Relaxation

Nuclear Peaking $(\mathrm{e})$

Source Term
Rod Assembly Batch (b)

45

38

32

$\left(z^{34}\right)$
Remarks (b)

Inconel spring relaxation is saturated and satisfactory.

No 1 imit reached.

(Designs) by vendors appear sat isfactory. Thermal limits may have to be raised (use of barrier fuel is required to achieve this).

No generic limits at current burnup levels, and none expected at extended burnups.

(a) Gigawatt-days per metric ton of initial heavy metal (GWd/MTIHM).

(b) The values in parentheses and the word (Design) refer to the capabi1ities of new or improved designs currently being offered by the vendors. Because the actual values are proprietary, they are indicated as being $\geq$ the current experience levels.

(c) By S. M. Stoller Corp.

(d) Operating procedures (PCIOMRs) that involve slow approaches to power.

(e) Thermal margins.

of the phenomena of concern with extended-burnup fuel, waterside corrosion of the cladding at burnups over 55,000 MHd/MTIHM remains the one with no immediate design solution. (22) Waterside corrosion of the cladding may become a life-limiting feature of fuel rod design for these higher burnups, in particular when combined with daily load-following operation. (42) A recent Westinghouse paper $(30)$ states that accelerated corrosion was observed in the last cycle (fifth) of exposure in the higher power regions of fuel that attained a burnup of 52,800 $\mathrm{MWd} / \mathrm{MTIHM}$--this underscores the importance of recognizing this effect when considering even longer fuel cycles and very high burnups. 
TABLE 3.13. Summary of Potential Limitations for Extended Burnup of PWR Fuel 9 (9)

\begin{tabular}{|c|c|c|c|c|}
\hline \multirow[b]{2}{*}{ Parameter } & \multicolumn{3}{|c|}{$\begin{array}{l}\text { Burnup Experience, } \\
\text { GWd/MTIHM (a) }\end{array}$} & \multirow[b]{2}{*}{ Remarks ${ }^{(b)}$} \\
\hline & $\begin{array}{l}\text { Fuel } \\
\text { Rod }\end{array}$ & $\begin{array}{c}\text { Fuel } \\
\text { Assembly }\end{array}$ & $\begin{array}{l}\text { Equivalent } \\
\text { Batch (b) }\end{array}$ & \\
\hline \multirow{2}{*}{$\begin{array}{l}\text { Zircaloy Growth: } \\
\quad 15 \times 15, \mathbb{W}(c)\end{array}$} & & 55 & 47 & One rod reached limit. \\
\hline & & & $(>47)$ & $\begin{array}{l}\text { Estimated (Design) limit for } \\
\text { new designs. }\end{array}$ \\
\hline $14 \times 14, C-E(d)$ & 55 & 52 & 45 & Considered reasonable limit. \\
\hline $17 \times 17, \underline{w}$ & 45 & & 37 & $\begin{array}{l}\text { Current limit of experience. } \\
\text { Performance is safisfactory; } \\
\text { it is estimated } \text { to be as } \\
\text { good as that of } 15 \times 15 \text {. }\end{array}$ \\
\hline $16 \times 16, C-E$ & & & 28 & Limit reached prematurely. \\
\hline & & & $(\geq 38)$ & (Design) is under development. \\
\hline Zircaloy Corrosion & 59 & & 49 & $\begin{array}{l}\text { No limit at this level. It } \\
\text { is estimated }(\mathrm{e}) \text { that a batch } \\
\text { average burnup of } 58 \mathrm{GWd} / \mathrm{MT} \text { IHM } \\
\text { may be achievable without heat } \\
\text { treated cladding for plants } \\
\text { with standard temperature } \\
\text { coolant. }\end{array}$ \\
\hline $\begin{array}{l}\text { Internal Rod } \\
\text { Pressure }\end{array}$ & 50 & & 42 & $\begin{array}{l}\text { No } l \text { imit at this level. It } \\
\text { is estimated }(\mathrm{e}) \text { that a batch } \\
\text { average burnup of } 58 \mathrm{GWd} / \mathrm{MT} \text { IHM } \\
\text { may be achievable. }\end{array}$ \\
\hline $\begin{array}{l}\text { Pellet-Cladding } \\
\text { Interaction in } \\
\text { Ramp Tests }\end{array}$ & 43 & & 35 & $\begin{array}{l}\text { Generally good performance. } \\
\text { High burnup achievable with } \\
\text { operating restrictions, if } \\
\text { that becomes necessary. }\end{array}$ \\
\hline $\begin{array}{l}\text { Zircaloy } \\
\text { Properties }\end{array}$ & & 55 & 47 & $\begin{array}{l}\text { No limit at this level. It } \\
\text { jt estimated }(\mathrm{e}) \text { that higher } \\
\text { levels are achievable but are } \\
\text { dependent on the rate of fur- } \\
\text { ther duct ility loss with } \\
\text { burnup. }\end{array}$ \\
\hline
\end{tabular}


TABLE 3.13. (contd)

Burnup Experience, GWd/MTIHM (a)

\begin{tabular}{|c|c|c|c|c|}
\hline Parameter & $\begin{array}{l}\text { Fuel } \\
\text { Rod }\end{array}$ & $\begin{array}{c}\text { Fue? } \\
\text { Assembly }\end{array}$ & $\begin{array}{l}\text { Equivalent } \\
\text { Batch }^{\text {(b) }} \\
\end{array}$ & Remarks (b) \\
\hline \multicolumn{5}{|l|}{ Spring Relaxation: } \\
\hline Inconel & & 55 & 47 & $\begin{array}{l}\text { Relaxation saturated and } \\
\text { satisfactory. }\end{array}$ \\
\hline Zircaloy & 55 & & 45 & $\begin{array}{l}\text { Satisfactory performance, but } \\
\text { almost no quantitative data. } \\
\text { Difficult to estimate addi- } \\
\text { tional potential. }\end{array}$ \\
\hline Nuclear Peaking $(f)$ & & & $\begin{array}{l}40 \\
(45)\end{array}$ & $\begin{array}{l}\text { No limit reached. } \\
\text { (Design) satisfactory. }\end{array}$ \\
\hline Source Term & & & & $\begin{array}{l}\text { No generic limits at current } \\
\text { burnup levels, and none } \\
\text { expected at extended burnup. }\end{array}$ \\
\hline
\end{tabular}
(a) Gigawatt-days per metric ton of initial heavy metal (GWd/MTIHM).
(b) The values in parentheses and the word (Design) refer to the capabi1- ities of new or improved designs currently being offered by the vendors. Because the actual values are proprietary, they are indicated as being $\geq$ the current experience levels.
(c) Westinghouse Electric Corporation (W).
(d) Combustion Engineering, Inc. (C-E).
(e) By S. M. Stoller Corp.
(f) Thermal margins.

Industry needs to develop a cladding alloy material (Zircaloy and zirconium alloys) that is highly resistant to waterside corrosion under all BWR and PWR operating conditions. (18) Nodular corrosion may be more of a concern as more BWRs load follow and extend burnup; Zircaloy corrosion is also a concern for PWRs. ${ }^{(18)}$ It is stated in a recent GE paper ${ }^{(33)}$ that it may well be required to develop modified Zircaloys or zirconium alloys that are more resistant to high-temperature, waterside corrosion to achieve targeted burnups. (33) Waterside corrosion and cladding ductility are considered to be potential problem areas for some plants. ${ }^{(8)}$ The corrosion of Zircaloy end plugs is also a fuel life-limiting factor at high burnup. ${ }^{\text {(31) Zircaloy }}$ 
cladding corrosion has become limiting in a few newer PWRs that have followed the trend to increase rod power or coolant outlet temperature to improve plant efficiency. (18)

Development is in progress on advanced cladding materials but irradiation exposure of the materials and subsequent evaluation will be required to mitigate the concern about waterside corrosion. ${ }^{(22)}$ An advanced Zircaloy cladding (ZIRLO) that contains niobium offers a significant improvement in corrosion resistance compared to Zircaloy-4 and is currently operating in demonstration assemblies in a commercia] PWR. $(23,24)$ According to a German paper, ${ }^{(41)}$ use of $2 r-2.5 \mathrm{Nb}$ alloy is very promising as a means of overcoming the burnup limitation due to corrosion in the case of Zircaloy. It is indicated in a recent paper ${ }^{(41)}$ that "Prime Candidate Alloy" (PCA), an improved Zircaloy-4, is being commercially introduced to overcome the present technological limitation on burnup of PWR fuel rods due to waterside corrosion. ${ }^{(41)}$

Significant decreases in the ductility of Zircaloy, in particular at low temperatures, have been measured in a 1 imited amount of mechanical property testing of highly irradiated fuel cladding. (27) The investigators ${ }^{(27)}$ indicate that it is not clear whether irradiation damage or hydrogen pickup is the dominant factor associated with the observed decrease in Zircaloy ductility. More test data are needed to identify the separate contributions of irradiation damage and hydrogen pickup on the ductility of highly irradiated Zircaloy-4. (27)

Accordingly to a recent GE paper, ${ }^{(33)}$ as a more statistically significant number of fuet assembiy components attain "ultra-high burnups" and fluences, Zircaloy is liable to be pushed to its operating limits.

The phenomena observed in high-burnup fuel (i.e., pellet-cladding bonding and pellets with porous rims) did not have any impact on fuel performance (i.e., no enhancement in fission-gas release or of pellet swelling has been noted) at the burnup levels studied. (31)

According to a recent German paper, ${ }^{(41)}$ fission gas pressure can become a limiting item for $8 \times 8$ BWR fuel at higher burnups, particularly under the conservative conditions that have to be applied for licensing analysis. 
Fuel rod and assembly bow is affected by differential Zircaloy growth, which is a potential burnup 1 imit; such growth can also cause bowing of BWR channels. (40) Results indicate that the rate of closure (due to bowing of fuel rods) between fuel rods decreased with increasing burnup and that at high burnup there was no excessive closure between rods. (18)

Results from overpower (ramp) tests indicate a rather sharp increase in failure threshold for PWR fuel rods under certain conditions, including very high burnup. ${ }^{(35)}$ However, several very high-burnup PWR fuel rods survived ramp testing beyond the level at which failure would be anticipated, based on other findings. (35)

Crud deposition is of concern when fuel rod discharge burnups are extended to about 50,000 MWd/MTIHM or higher. ${ }^{(42)}$

Whole-core fuel cleaning may become important as more plants try to reduce radiation levels in the future. ${ }^{(18)}$ The effects of cleaning agents on subsequent fuel performance in the reactor (and aiso in subsequent storage) will need to be understood; there will probably also be a need to reirradiate some cleaned test assemblies. (18)

It is noted in a recent paper ${ }^{(31)}$ on activities in Sweden and Finland that as yet no technical difficulties have occurred that would prevent raising the discharge burnup to a peak pellet value of about 55 GWd/MTIHM.

The West Germans ${ }^{(37)}$ have a complete PWR fuel assembly, which contains fuel rods with burnups of $\leq 43,000 \mathrm{MWd} / \mathrm{MTIHM}$, involved in a dry storage experiment; the analysis of the behavior of the fuel rods in dry storage thus far indicates that the design of storage facilities is limited only by the spent fuel insertion temperature and not by the storage method. They do not use an air environment in their storage system.

\subsection{EFFECT OF EXTENDED-BURNUP FUEL ON HANDLING, STORAGE, AND OTHER} OPERATIONS

The effect of extended-burnup fuel on handling, interim storage, and other operations (e.g., rod consolidation and shipping) subsequent to reactor service is described in the three subsections below. There is one important 
general comment that applies to the irradiation, handling, interim storage, rod consolidation, and shipping of extended-burnup LWR fue1. It is concluded in a 1985 report $^{(38)}$ and a 1985 paper $^{(39)}$ that extending burnup even to $60,000 \mathrm{MWd} / \mathrm{MTIHM}$ results, in general, in environmental consequences that are either less than or virtually the same as those assumed in current regulations.

\subsubsection{Handling}

The impact of extended-burnup LWR spent fuel assemblies on handling was evaluated in a recent report: ${ }^{(9)}$ it was concluded (based on available data) that both BWR and PWR fuel assemblies with burnups up to 45 GWd/MTIHM should present no problems (i.e., that are reiated to the strength of their main structural components) for handling in spent fuel storage pools or during handling associated with the back end of the fuel cycle. In a recent paper ${ }^{(97)}$ on spent fuel management, it is noted that there are at least 25 fuel assembiy types with a wide variety of burnups to be considered.

Handling and reconstitution experience with extended-burnup fuel deserves some attention to prepare for future rod consolidation campaigns. ${ }^{(12)}$

Crud deposits typically consist of individual agglomerated particles ranging in size from 0.1 to 10 microns; particulates in that size range would become airborne if they are released during dry fuel handling operations, and, hence, facility designs must be able to accommodate such airborne releases. (47) Further crud characterization studies (emphasis should be placed on estimating fractional crud releases from spent fuel for various handling and transporting operations) should be undertaken to provide support for ongoing handling facility designs and future licensing actions. (47)

In a recent study of the economics of extending the fuel cycle life to 24 months, ${ }^{(46)}$ it is noted that included among current activities are efforts to qualify fuel handiing and storage facilities for fuel enrichments up to 5 wt\% uranium-235. Most PWRs were originally designed for burnups in the 27 to $33 \mathrm{GWd} / \mathrm{MTIHM}$ range with corresponding initial enrichments of 2.6 to 3.2 wt\% uranium-235; the spent fuel storage pools were typically designed for enrichments of 3.5 to 4.0 wt\% uranium- 235 . 
Current7y, the NRC provides guidelines to industry for analyzing fuel handling accidents in fuel handling and storage facilities at BWRs and PWRs for fuel with burnups to 38,000 MWd/MTIHM. $(98,99)$ Because extended-burnup fuel programs can involve fuel with substantially higher burnup levels, some additional guidance may be needed in analyzing fuel handling accidents involving fuel with burnups greater than $38,000 \mathrm{MWd} / \mathrm{MTIHM}$. (11)

\subsubsection{Storage}

The main impact of extending fuel burnup on wet and dry storage and rod consolidation is the reduction in the total requirements for fuel storage and in the total quantity of fuel that must be consolidated. (43) The quantities of spent LWR fuel discharged decrease as the burnup is increased, which wi1l free up storage space in at-reactor pools. ${ }^{(5)}$ The effect of extending burnup by $1.0,2.0$, and $3.0 \%$ per year on the projected cumulative domestic storage requirements is illustrated in Table 3.14. Other issues that are involved

IABLE 3.14. Projected Cumulative Storage Requirements in the U.S. ${ }^{(100)}$

\begin{tabular}{|c|c|c|c|c|}
\hline \multirow[b]{2}{*}{ Year } & \multicolumn{4}{|c|}{ Number of Fuel Assemblies } \\
\hline & $\begin{array}{l}\text { Maximum } \\
\text { At-Reactor } \\
\text { Capacity } \\
\text { Case } \\
\end{array}$ & $\begin{array}{c}\text { Maximum } \\
\text { At-Reactor } \\
\text { Capacity Plus } \\
1.0 \% / \text { Year } \\
\text { Exposure Case } \\
\text { (b) }\end{array}$ & $\begin{array}{c}\text { Maximum } \\
\text { At-Reactor } \\
\text { Capacity Plus } \\
2.0 \% / \text { Year } \\
\text { Exposure Case (b) }\end{array}$ & $\begin{array}{c}\text { Maximum } \\
\text { At-Reactor } \\
\text { Capacity Plus } \\
3.0 \% / \text { Year } \\
\text { Exposure Case } \\
\text { (b) }\end{array}$ \\
\hline 1990 & 1,129 & 1,195 & 1,121 & 1,050 \\
\hline 1995 & 6,890 & 7,034 & 6,349 & 5,904 \\
\hline 2000 & 24,157 & 22,381 & 19,381 & 17,514 \\
\hline $2003^{(c)}$ & 39,592 & 36,692 & 31,908 & 28,936 \\
\hline 2005 & 51,308 & 46,055 & 40,147 & 36,306 \\
\hline
\end{tabular}

(a) Utility projected discharges.

(b) Assumes the given percentage increase in exposure starts in 1987. The maximum average discharge exposure was assumed to be 38,000 megawatt-days (thermal) per metric ton of initial heavy metal (MWd/MTIHM) for BWR fuel and 45,000 MWd/MTIHM for PWR fuel.

(c) It is estimated that the spent fuel storage pools at some domestic 1 ight-water reactors will run out of space before 2003, the year that the U.S. Department of Energy currently predicts it will have a repository available. 
are the design modifications necessary to accommodate the higher initial enrichment, heat load, and source term. (43) Those technical modifications or design changes to accommodate extended-burnup fuel do not unduly stretch the current storage and consolidation equipment or designs and are economically attractive. (43)

Anticipated changes in the characteristics of the fuel assemblies due to extended burnups are not expected to jeopardize the spent fuel during storage in water. ${ }^{(10)}$ For waste management planning and repository design, it will be important to continue to monitor the behavior of intact and defective (i.e., failed or damaged) spent fuel that is placed in wet and dry storage to gain additional evidence, in particular with higher burnup fuel, that fuel integrity is being appropriately maintained. ${ }^{(3)}$

Credit for burnup has been allowed in spent fuel pools at domestic reactors for a number of years. (101) currently, there are about a dozen domestic reactors that have storage pools licensed to account for burnup. (102) Use of burnup credit in spent fuel storage equipment for extended-burnup fuel can result in the elimination of the use of poison material, which is an advantage in that it is then not necessary to be concerned with degradation of the poison material over time and exposure. ${ }^{(43)}$ Regarding credit for burnup in spent fuel storage rack design, several experiments have been conducted with unirradiated fuel that included the major features of fuel racks; however, no such experiments have been performed with irradiated fuel. ${ }^{(44)}$ There is an uncertainty that needs to be considered in PWR fuel storage racks: results of criticality studies on the storage of spent PWR fuel reveal that, for burnups above about 27,000 MWd/MTIHM, the more highly reactive ends of the fuel assemblies result in a positive reactivity increment, an effect that is not observed in the reactor core. ${ }^{(45)}$

Extending fuel burnup can potentially cause some minor distortions in the design of storage/transport casks and fuel consolidation equipment because increasing the burnup adversely affects the radiological and thermal designs of such systems but is beneficial to criticality aspects. 


\subsubsection{0ther Operations (e.g., Rod Consolidation and Shipping)}

The impacts on the design of rod consolidation equipment from burnupenhanced fue $T$ phenomena are listed in Table 3.15. (6) The degradation of the mechanical and structural properties noted in extended-burnup fuel needs to be considered in planning rod consolidation operations. ${ }^{(43)}$ Designers of rod consolidation equipment will have to provide sturdier equipment to accommodate the harder materials (they are more difficult to cut) associated with extended-burnup fuel. ${ }^{(6)}$

Extending fuel burnup is a benefit in the criticality design of consolidation and dry spent fuel storage systems. ${ }^{(43)}$ Regarding underwater rod consolidation operations, once-burned fuel rather than extended-burnup fuel will present the worst case in criticality analyses. ${ }^{(6)}$

Currently available transportation casks can carry extended burnup fuel at their design capacity, unless they are limited because of criticality concerns. ${ }^{(5)}$ It is possible to use heavily poisoned baskets to obtain criticality control in spent-fuel casks; however, burnup credit is a much more direct means of demonstrating criticality safety for licensing. ${ }^{(48)}$ Cask capacities would not be reduced if the NRC permits burnup credit in criticality calculations and the spent fuel is cooled sufficiently at the reactor sites. (5)

IABLE 3.15. Burnup-Enhanced Fuel Phenomena and Impacts on the Design of Rod Consol idation Equipment. (6)

Phenomena

Fuel rod bow

Material embrittlement

Handling damage

Decay heat

Reactivity and radioactivity

Stress relaxation
Impacts

Rod pulling and handling

Rod pulling and compaction of nonfuel-bearing structural components

Rod pulling and fuel assembly handling

Cooling of canisters and equipment

Shielding and criticality

Rod pulling 
Increased radiation and heat sources produced in the fuel and the higher initial uranium-235 enrichment are the principal effects of extended-burnup fuel on spent fuel casks. (48) Increasing the burnup of PWR fuel from 40 to $70 \mathrm{GWd} /$ MTIHM will increase the heat generated (10 years after discharge) by about $70 \%$ and the total radioactivity by about half that amount. $(6,103)$ The increased heat and gamma radiation from extended-burnup fuel can be accommodated by additional cooling time, but the increased neutron radiation (principal emitters are ${ }^{242} \mathrm{Cm}$ and ${ }^{244} \mathrm{Cm}$ ) cannot be accommodated unless the balance of gamma and neutron contributions to the overall dose rate is properly selected initially. ${ }^{(48)}$

Regarding spent fuel shipments, it is indicated in a 1988 paper(104) that for the majority of the BWR and PWR spent fuel population, the crud activity deposits are so small that crud is not a significant contributor to the source term or to the allowable leakage rate. 


\subsection{REFERENCES}

1. General Accounting Office, DOE Needs to Evaluate Fully the Waste Management Effects of Extending the Useful Life of Nuclear Fuel, GA0/RCED-84-III, January 27, 1984.

2. Atomic Energy Clearing House 30(8):3-5 (February 20, 1984), Congressional Information Bureau, Inc., Washington, DC 20005.

3. Bailey, W. J. 1987. Categorization of Failed and Damaged Spent LWR Fuel Currently in Storage. PNL -5882 , Pacific Northwest Laboratory, Richland, Washington. (Note: DOE/EIA's estimate of the number of defective fuel assemblies in storage as of CY 1987 was lower than they reported as of CY 1986 in PNL-5882).

4. Lang, P. M. 1988. "A Forward Look At Improvements in Fuel Utilization and Performance," International Conference on Nuclear Power Performance and Safety. CONF IAEA-CN-48/190, Vol. 5, p. 491. International Atomic Energy Agency, Vienna, Austria. (Conference was held in Vienna, Austria, September 28-October 2, 1987)

5. Office of Civilian Radioactive Waste Management. June 1985. A Study of the Costs and Benefits of Extended Burnup. Office of Nuclear Energy, U.S. Department of Energy.

6. Matheson, J. E. 1986. "The Application of High-Burnup Experience to Consolidation Equipment Design." In Trans. Am. NucT. Soc. 53:108-109 (November 1986). Copyright 1986 by the Anerican Nuclear Society, LaGrange Park, Illinois.

7. Pyecha, T. D., et a1. 1985. "Waterside Corrosion of PWR Fuel Rods Through Burnups of 50,000 MWd/MTU." In Light Water Reactor Fuel Performance, DOE/NE/34130-1, Vol. 1, pp. 3-17 through 3.35.

8. Beyer, C. E., and R. Lobel. 1987. "Licensing Fuel for Extended Burnup Operation." In Irans. Am. Nucl. Soc. 54(Supplement 1):92-93 (AugustSeptember 1987). Copyright 1987 by the American Nuclear Society, LaGrange Park, Illinois.

9. Franks, W. A., and L. Geller, 1986. The Benefit of Extended Burnup in Fuel Cycle Cost. SAND86-7089, S. M. Stoller Corp., New York, New York.

10. Johnson, A. B., Jr., and W. J. Bailey. 1982. "Assessment of Interim Storage of Spent High-Burnup LWR Fuel." In Trans. Am. Nucl. Soc. (International ENS/ANS Conference) 40:150-151 (April 1982). Copyright - 1982 by the American Nuclear Society, LaGrange Park, Illinois.

11. Bailey, W. J. 1985. Some Factors to Consider in Handling and Storing Spent Fuel. PNL-5395, Pacific Northwest Laboratory, Richland, Washington. 
12. Johnson, A. B., Jr., W. J. Bailey, and K. Klein. 1987. "Wet Storage in the USA: Recent Experience and Directions." In Long-Term Wet Spent Nuclear Fuel Storage, IAEA-TECDOC-418 (Proceedings of a Technical Committee Meeting on Behavior of Used Fuel Assemblies and Storage Equipment at Long Term Wet Storage Conditions, held in Leningrad, USSR, May 26-30, 1986), pp. 47-57, International Atomic Energy Agency, Vienna, Austria.

13. Bailey, W. J. 1987. Rod Consolidation of RGQE'S Spent PWR Fuel. PNL-6162, Pacific Northwest Laboratory, Richland, Washington.

14. Bassler, E. A. 1984. "Westinghouse Fuel Consolidation Experience." In Proceedings of the Institute of Nuclear Materials Management Spent Fuel Management Seminar I, which was held in January 1984 in Washington, D.C.

15. Duke Power Company and Westinghouse Electric Corporation. 1983. Spent Fuel Consolidation Demonstration-Oconee Nuclear Station, Fall 1982.

16. Baker, D. A., et al. 1988. Assessment of the Use of Extended Burnup Fuel in Light Water Power Reactors. NUREG/CR-5009 (PNL-6258).

17. Suprenant, M. A. 1988. "Fuel Performance at Northeast Utilities." In Proceedings of the American Nuclear Society International Topical Meeting on LWR Fuel Performance, pp. 328-331, Williamsburg, Virginia, April 17-20, 1988 . Copyright 1988 by the American Nuclear Society, LaGrange Park, Illinois. (ISBN 0-89448-032-4, ANS Order No. 700131)

18. Franklin, D., U. Wolff, and D. O'Boyle. 1988. "A Utility Perspective on LWR Fuel Performance." In Proceedings of the American Nuclear Society International Topical Meeting on LWR Fuel Performance, pp. 3-11, Witliamsburg, Virginia, Apri] 17-20, 1988. Copyright 1988 by the American Nuclear Society, LaGrange Park, Illinois.

(ISBN 0-89448-032-4, ANS Order No. 700131)

19. Ritter, G. L., et a1. 1987. "Prospects for Improvement of Fuel Performance and Fuel Cycle cost in BWRs and PWRs in the Nineties." In Trans. Am. Nucl. Soc. 56 (Supplement No. 1):485-490 (September 1987). Copyright $\odot 1987$ by the American Nuclear Society, LaGrange Park, Illinois.

20. Matheson, J. E., L. W. Newman, W. A. McInteer, and G. M. Bain. 1985. "Recent Operating Experience with B\&W Fuel with the Emphasis on Extended Burnup." In Light Water Reactor Fuel Performance, DOE/NE/34130-1, Vol. 1, pp. 2-47 through 2-62.

21. Andrews, M. G., and R. A. Matzie. 1985. "A Report on the Reliability, Performance and Progress of Combustion Engineering's Fuel Assemblies Toward Extended Burnup." In Light Water Reactor Fuel Performance, DOE/NE/34130-1, VoT. 1, pp. 2-33 through 2-45. 
22. Newman, L. W., et a1. 1986. The Hot Ce17 Examination of Oconee-1 Fuel Rods After Five Cycles of Irradiation, DOE/ET/34212-50 (BAW-1874), Babcock \& Wilcox Company, Lynchburg, Virginia.

23. Slember, R. J., and P. K. Doshi. 1987. "Recent Advances in Fuel Product and Manufacturing Process Development." In Trans. Am. Nuc]. Soc. 56(Supplement No. 1):446-453 (September 1987). Copyright 1987 by the American Nuclear Society, LaGrange Park, Illinois.

24. Doski, P. K., D. L. Chapin, and L. R. Scherpereel. 1988. "Westinghouse VANTAGE+ Fuel Assembly to Meet Future Operating Requirements." In Trans. Am. Nuc]. Soc. 56:118-119 (June 1988). Copyright 1988 by the American Nuclear Socjety, LaGrange Park, I11 inois.

25. Sofer, G. A., et a1. 1988. "Performance of Advanced Nuclear Fuels Corporation Fuel in Light Water Reactors." In Proceedings of the American Nuclear Society International Topical Meeting on LWR Fuel Performance, pp. 41-53, Williamsburg, Virginia, April 17-20, 1988. Copyright 1988 by the American Nuclear Society, LaGrange Park, Illinois. (ISBN 0-89448-032-4, ANS Order No. 700131)

26. Newman, L. H., and H. A. Hassan. 1988. "Fuel Performance Overview." In Proceedings of the American Nuclear Socjety International Topical Meeting on LWR Fuel Performance, pp. 81-89, Williamsburg, Virginia, April 17-20, 1988. Copyright 1988 by the American Nuclear Society, LaGrange Park, Il] inois. (ISBN 0-89448-032-4, ANS Order No. 700131)

27. Andrews, M. G., G. P. Smith, and M. A. Shubert. 1988. "Experience and Developments with Combustion Engineering Fue1." In Proceedings of the American Nuclear Society International Topical Meeting on LWR Fuel Performance, pp. 90-95, Williamsburg, Virginia, April 17-20, 1988. Copyright 1988 by the American Nuclear Society, LaGrange Park, Illinois. (ISBN 0-89448-032-4, ANS Order No. 700131)

28. Baily, W. E., et a]. 1988. "Performance Experience of GE Boiling Water Reactor Fuel." In Proceedings of the American Nuclear Socjety International Topical Meeting on LWR Fuel Performance, pp. 12-20, Williamsburg, Virginia, Aprit 17-20, 1988. Copyright 1988 by the American Nuclear Society, LaGrange Park, 111 inois. (ISBN 0-89448-032-4, ANS Order No. 700131)

29. Proebstle, R. A., and H. H. Klepfer. 1987. "Fuel PerformanceExperience to Date and Future Potential." In Trans. Am. Nucl. Soc. 56(Supplement No. 1):491-496 (September 1987). Copyright 1987 by the American Nuclear Society, LaGrange Park, Illinois. 
30. Kaiser, R. S., et al. 1988. "Westinghouse High Burnup Experience at Farley 1 and Point Beach 2." In Proceedings of the American Nuclear Society International Topical Meeting on LWR Fuel Performance, pp. 119. 124, Wi1liamsburg, Virginia, April 17-20, 1988. Copyright 1988 by the American Nuclear Society, LaGrange Park, 111 inois. (ISBN 0-89448-0324, ANS Order No. 700131)

31. Grapenigiesser, B., et a1. 1988. "High Burnup Fuel Evaluation Activities in Sweden and Fintand." In Proceedings of the American Nuclear Society International Topical Heeting on LWR Fuel Performance, pp. 31-40, Williamsburg, Virginia, April 17-20, 1988. Copyright 1988 by the American Nuclear Society, LaGrange Park, Illinois.

(ISBN 0-89448-032-4, ANS Order No. 700131)

32. Haas, D. 1988. "Status of the Tribulation Programme." In Proceedings of the American Nuclear Society International Topical Meeting on LWR Fuel Performance, pp. 245-252, Williamsburg, Virginia, April 17-20, 1988. Copyright 1988 by the American Nuclear Society, LaGrange Park, Illinois. (ISBN 0-89448-032-4, ANS Order No. 700131)

33. Adamson, R. D., B-C Cheng, and R. P. Tucker. 1987. "Aspects of ZircaToy Core Materials for Advanced LWRs." In Irans. Am. Nucl. Soc. 55:254-255 (November 1987). Copyright 1987 by the American Nuclear Society, LaGrange Park, Illinois.

34. Joseph, J., J. Royer, and M. Grosgeorge, 1988. "Transient Behaviour of FRAGEMA Fuel Rods Previously Irradiated Under Commercial Reactor Operating Conditions." In Proceedings of the American Nuclear Society International Topical Meeting on LWR Fuel Performance, Pp. 225-231, Williamsburg, Virginia, Aprif 17-20, 1988. Copyright 1988 by the American Nuclear Society, LaGrange Park, I11inois. (ISBN 0-89448-032-4, ANS Order No. 700131)

35. Kjar-Pedersen, N. 1986. "Fuel Operational Limits Based on Studsvik International Projects Data." In Irans. Am. Nuc1. Soc. 52:604-607 (June 1986). Copyright 1986 by the American Nuclear Society, LaGrange Park, Illinois.

36. Knudsen, P., et al. 1988. "Fission Gas Release in High-Burnup Fuel During Power Transients." In Proceedings of the American Nuclear Society International Topical Meeting on LWR Fuel Performance, pp. 89-203, Williamsburg, Virginia, April 17-20, 1988. Copyright 1988 by the American Nuclear Society, LaGrange Park, I1linois.

(ISBN 0-89448-032-4, ANS Order No. 700131)

37. Peehs, M., R. Kühne], and G. Kaspar. 1982. "Discussion of Spent LWR Fuel Properties in Relation to Actual Long-Term Storage Concepts." In Trans. Am. Nuc]. Soc. (International ENS/ANS Conference) 40:135 (Apri] 1982). Copyright 1982 by the American Nuclear Society, LaGrange Park, Illinois. 
38. Leiper, A. S. June 1985. The Environmental Consequences of Higher Fuel Burnup, AIF/NESP-032.

39. Mauro, J. J., R. Eng, and T. A. Coleman. June 1985. "Environmental Impacts of the Uranium Fuel Cycle at Extended Burnups," Trans. Am. Nucl. Soc. 48:54-56. Copyright $\odot 1985$ by the American Nuclear Socjety, LaGrange Park, Illinois.

40. Strasser, A. A., and D. K. Sheppard. 1987. "Achieving Improved Fue1 Reliability." In Irans. Am. Nucl. Soc. 54(Supplement 1):165-167 (August-September 1987). Copyright 1987 by the American Nuclear Society, LaGrange Park, Illinois.

41. Holzer, R., and H. Knabb. 1988. "Recent Fuel Performance Experience and Implementation of Improved Products." In Proceedings of the American Nuclear Society Internationa] Topical Meeting on LWR Fuel Performance, pp. 69-80, Williamsburg, Virginia, April 17-20, 1988. Copyright 1988 by the American Nuclear Society, LaGrange Park, Illinois. (ISBN 0-89448-032-4, ANS Order No. 70013I)

42. Pan, C., B. G. Jones, and A. J. Machie1s. 1987. "Effects of Crud Deposition on Zircaloy Corrosion." In Irans. Am. Nucl. Soc. 55:303-305 (November 1987). Copyright 1987 by the American Nuclear Society, LaGrange Park, Illinois.

43. Anderson, C. K., W. J. Burns, and R. J. Klotz. 1986. "Optimization of Spent-Fuel Storage Equipment with Extended Burnup." In Irans Am. Nucl. Soc. 53:104-105 (November 1986). Copyright ${ }^{\circ} 1986$ by the American Nuclear Society, LaGrange Park, Il Tinois.

44. Brooks, W. L. 1987. "Credit for Burnup in Spent-Fuel Storage Rack Design-Regulatory Perspective." In Irans. Am. Nucl. Soc. 55:400 (November 1987). Copyright 1987 by the American Nuclear Society, LaGrange Park, Illinois.

45. Turner, S. E. 1987. "Storage of Burned PWR and BWR Fuel. In Trans. Am. Nucl. Soc. 55:394-395 (November 1987). Copyright 1987 by the American Nuclear Society, LaGrange Park, Illinois.

46. Anderson, C. K. 1988. "Extended Cycle Length Economics." In Irans. Am. Nucl. Soc. 56:116-117 (June 1988). Copyright 1988 by the American Nuclear Society, LaGrange Park, I11 inois.

47. Jardine, L. J. 1986. "Preliminary Characterization of Radioactive Crud for Design of Dry Spent-Fuel Handling Facilities." In Trans. Am. Nucl. SoC. 53:120-121 (November 1986). Copyright 1986 by the American NucTear Society, LaGrange Park, Il1inois.

48. We11s, A. H. 1986. "Effects of High Burnup on Spent-Fuel Casks." In Trans. Am. Nucl. Soc. 53:108 (November 1986). Copyright 1986 by the American Nuclear Society, LaGrange Park, Illinois. 
49. Fuel and Pool Component Performance in Storage Pools, EPRI NP-4561, Copyright 1986, Electric Power Research Institute, Palo Alto, California, May 1986. Reprinted with permission.

50. Pati, S. R., A. M. Garde, and L. J. Clink. 1988. "Contribution of Pellet Rim Porosity to Low-Temperature Fission Gas Release at Extended Burnups." In Proceedings of the American Nuclear Society International Topical Meeting on LWR Fuel Performance, pp. 204-215, Williamsburg, Virginia, April 17-20, 1988. Copyright 1988 by the American Nuclear Society, LaGrange Park, I1l inois. (ISBN 0-89448-032-4, ANS Order No. 700131)

51. Kaiser, R. S., et a1. 1987. "High-Burnup Experience at Farley 1 and Point Beach 2." In. Trans. Am. Nucl. Soc. 54(Supplement 1):91-92 (August-September 1987). Copyright 1987 by the American Nuclear Society, LaGrange Park, Illinois.

52. Ocken, H. 1988. "Decontamination of BWR Fuel Bundles." In Trans. Am. Nucl. Soc. 56(Supplement No. 2):76-77 (April 1988). Copyright 1988 by the American Nuclear Society, LaGrange Park, I11inois.

53. Bailey, W. J., and S. Wu. 1988. Fuel Performance Annual Report for 1986, NUREG/CR-3950 (PNL-5210) Vol. 4. U.S. Nuclear Regulatory Commission, Washington, D.C.

54. Bailey, W. J., C. J. Morris, F. R. Reich, and K. L. Swinth. July 1980. Assessment of Current Onsite Inspection Techniques for Light-Water Reactor Fuel Systems: Executive Summary. NUREG/CR-1380 (PNL-3325), Vol. 1, U.S. Nuclear Regulatory Commission, Washington, D.C.

55. Bailey, W. J., C. J. Morris, R. F. Reich, and K. L. Swinth. January 1981. Assessment of Current Onsite Inspection Techniques for LightWater Reactor Fuel Systems: Discussion of Inspection Techniques. NUREG/CR-1380 (PNL-3325), Vol. 2, U.S. Nuclear Regulatory Commission, Washington, D.C.

56. Wilson, H., et al. 1988. "A Comparison of Ultrasonic and Gas Sipping Leak Detection Techniques." In Proceedings of the American Nuclear Society International Topical Meeting on [WR Fuel Performance, pp. 297 303, Wi11iamsburg, Virginia, Apri1 17-20, 1988. Copyright 1988 by the American Nuclear Society, LaGrange Park, Illinois. (ISBN 0-89448-032-4, ANS Order No. 700131)

57. Eickelpasch, N., and K. Baur. 1988. "Methods of At-Reactor Fue] Examination and Repair and Selected Results for German LWRs." In Proceedings of the American Nuclear Society International Topical Meeting on LWR Fuel Performance, pp. 321-327, Williamsburg, Virginia, Apri] 17-20, 1988. Copyright 1988 by the American Nuclear Society, LaGrange Park, I1linois. (ISBN 0-89448-032-4, ANS Order No. 700131) 
58. Pilat, E. E. 1987. "Why Reliability is the Most Important Aspect of Fue] Design for a Utility." In Trans. Am. Nucl. Soc. 55:107 (November 1987). Copyright 1987 by the American Nuclear Society, LaGrange Park, Illinois.

59. Boyer, V. S., and J. J. Taylor. 1986. "R\&D Improvements from Operating Experience in the United States." In ENC'86 Transactions (Incorporates ENC-4: Fourth International ENS/ANS Conference and Foratom IX: Ninth Foratom Congress) 1:135-165.

60. Fader, G. B. 1987. "Industrywide Nuclear Power Plant Performance Indicator Program." In Irans. Am. Nucl. Soc. 54(Supplement 1):49 (August-September 1987). Copyright 1987 by the American Nuclear Society, LaGrange Park, Illinois.

61. EPRI Research and Development Program P7an, 1987-1989, Copyright 1987, Electric Power Research Institute, Palo Alto, Cal ifornia, January 1987. Reprinted with permission.

62. Lang, P. M., et a1. 1983. "Improvements in LWR Fue1 Utilization". In Nuclear Power Experience 3:621-633, International Atomic Energy Agency, Vienna, Austria.

63. Roberts, E. 1982. "Extended Burnup Considerations and Experience." In Proceedings of the American Nuclear Society International Topical Meeting on LWR Extended Burnup Fuel Performance and Utilization, pp. 1-1 through 1-3. DOE/NE/34087, Vol. 1, American Nuclear Society, Virginia Section, Lynchburg, Virginia.

64. Frank7in, D., et al. 1987. "Advances in Light Water Reactor Fuels." In Trans. Am. Nucl. Soc. 55:255-257 (November 1987). Copyright 1987 by the American Nuclear Society, LaGrange Park, Illinois.

65. $0 i$, N., et al. 1988. "BWR Fuel Performance and Recent Trend of R\&D in Japan." In Proceedings of the American Nuclear Society International Topical Meeting on LWR Fuel Performance, pp. 21-30, Willi amsburg, Virginia, April 17-20, 1988. Copyright 1988 by the American Nuclear Society, LaGrange Park, Illinois. (ISBN 0-89448-032-4, ANS Order No. 700131)

66. Rowland, T. C., R. M. Ikemoto, and S. GehT. 1986. "Performance of Boiling Water Reactor Fuel Lead Test Assemblies to $35 \mathrm{MWd} / \mathrm{kgU}$." In Trans Am. Nucl. Soc. 53:89-90 (November 1986). Copyright 1986 by the American Nuclear Society, LaGrange Park, I17 inois.

67. Noble L. D., et al. 1987. "Recent BWR Fuel Experience." In Irans. Am. Nucl. Soc. 54 (Supplement 1):164-165 (August-September 1987). Copyright 1987 by the American Nuclear Society, LaGrange Park, Illinois. 
68. Montgomery, R. O. and M. Billaux. 1987. "ZORITA Fuel Performance Project Evaluation with COMETHE III-L." In Trans. Am. Nucl. Soc. 55:292-293 (November 1987). Copyright 1987 by the American Nuclear Society, LaGrange Park, Illinois.

69. Habermeyer, J. A., S. Y. Ogawa, and J. R. Ingvoldstad (compilers). 1982. BWR Fuel-Bundle Extended-Burnup Program. DOE/ET/34031-8 (GEAP-22160).

70. 0'Leary, A. H., and K. E. Karcher. 1988. "Performance of Gadol inia Burnable Absorber Assemblies at Burnups up to 50,000 MWd/MTU." In Proceedings of the American Nuclear Society International Topical Meeting on LWR Fuel Performance, Pp. 348-355, Williamsburg, Virginia, April 17-20, 1988. Copyright 1988 by the American Nuclear Society, LaGrange Park, I11inois. (ISBN 0-89448-032-4, ANS Order No. 700131)

71. Moon, J. 1987. Farley Unit 1, EOC-7, 17x17 OFA Onsite Examinations Report, WCAP-11561, Westinghouse Electric Corporation, Pjttsburgh, Pennsylvania.

72. Sofer, G. A. 1982. "Technology of Burnable Absorber Reactivity Control and Other Techniques to Increase Fuel Burnup in LWR Fuel Cycles." In Irans. Am. NuCl. Soc. (International ENS/ANS Conference) 40:183-184 (April 1982). Copyright 1982 by the American Nuclear Society, LaGrange Park, Illinois.

73. Schmiedel, P., and H. Schöning. 1987. "Design, Fabrication and InCore Management of Advanced Fuel Assemblies for LWRs." In Trans. Am. Nucl. Soc. 56 (Supplement No. 1):480-483 (September 1987). Copyright 0 1987 by the American Nuclear Society, LaGrange Park, Illinois.

74. Bailey, W. J., S. Wu, and R. Lobel. 1987. "Fuel Performance in the United States." In Trans. Am. Nucl. Soc. 54(Supplement 1):161-162 (August-September 1987). Copyright 1987 by the American Nuclear Society, LaGrange Park, I1linois. (PNL-SA-14600).

75. Peterman, K. W., and A. J. B7 amey. 1988. "Quad Cities 2 Load Follow Demonstration with General Electric Barrier Fuel." In Proceedings of the American Nuclear Society International Topical Meeting on LWR Fuel Performance, pp.154-162, Williamsburg, Virginia, Apri1 17-20, 1988. Copyright 1988 by the American Nuclear Society, LaGrange Park, Il1 inois. (ISBN 0-89448-032-4, ANS Order No. 700131)

76. Cunningham, S. E., et al. 1988. "ZrB, Integral Fuel Burnable Absorber Rod Performance." In Proceedings of the American Nuclear Society International Topical Meeting on LWR Fuel Performance, pp. 343-347, Williamsburg, Virginia, April 17-20, 1988. Copyright 1988 by the American Nuclear Society, LaGrange Park, I11inois. (ISBN 0--89448-032-4, ANS Order No. 700131) 
77. Moss, H. D., (compiler). 1982. Extended Fuel Burnup Demonstration Program, Semiannua] Technical Progress Report for the Period from July 1981 through December 1981, WCAP-10199 (DOE/ET/34014-5).

78. Smith, G. P. 1987. The Evaluation and Demonstration of Methods for Improved Nuclear Fuel Utilization, Tenth Progress Report: July 1, 1985 to December 31, 1986. DOE/ET/34013-13 (CEND-429).

79. Arbiter, W., and J. A. Kuszyk. 1984. Surry Unit 2 End of Cycle 5 Onsite Examination of $17 \times 17$ Demonstration Fuel Assembly RD-2 After Four Crcles of Exposure, WCAP-10317 (DOE/ET-34014-13), Volume 1.

80. Anderson, C. K., et a1. 1987. "Advanced PWR Fuel Design Concepts." In Trans. Am. Nucl. Soc. 56 (Supplement No. 1):439-445 (September 1987). Copyright $\odot 1987$ by the American Nuclear Socjety, LaGrange Park, Illinois.

81. Lindquist, K. O., S.T.C. Hsieh, and T. C. Haley. 1987. "Benchmarking and Modification of FRAPCON2 V1 MOD5." In Irans. Am. Nucl. Soc. 55:287-289 (November 1987). Copyright 1987 by the American Nuclear Society, LaGrange Park, Illinois.

82. Baron, D., C. Forat, and E. Maffeis. 1988. "FRAGEMA Experience on Fission Gas Release Under Base and Transient Operating Conditions." In Proceedings of the American Nuclear Society International Topical Meeting on LWR Fuel Performance, pp. 216-222, Williamsburg, Virginia, April 17-20, 1988. Copyright 1988 by the American Nuclear Society, LaGrange Park, I1]inois. (ISBN 0-89448-032-4, ANS Order No. 700131)

83. Garde, A. M. 1986. Hot Cell Examination of Extended Burnup from Fort CaThoun, DOE/ET/34030-11 (CEND-427).

84. Simon, M., and P. Courcier. 1985. "PWR Nuclear Fuel Design and Manufacturing Technology Transfer." In Irans. Am. Nucl. Soc. 51:232-233 (October 1985). Copyright 1985 by the American Nuclear Society, LaGrange Park, Illinois.

85. Billaux, M., P. Blanpain, and D. Boulanger. 1988. "Evaluation of the Thermomechanical Properties of High Burnup Gadolinia Fuel." In Proceedings of the American Nuclear Society International Topical Meeting on LWR Fuel Performance, pp. 356-363, Williamsburg, Virginia, April 1720, 1988. Copyright 1988 by the American Nuclear Society, LaGrange Park, Illinois. (ISBN 0-89448-032-4, ANS Order No. 700131)

86. Shallenberger, J. M., J. F. Wilson, and R. P. Knott. 1987. "PWR Fue] Features to Preclude Externally Induced Damage." In Trans. Am. Nucl. Soc. 54(Supplement 1):160-161 (August-September 1987) Copyright ${ }^{-}$ 1987 by the American Nuclear Society, LaGrange Park, Illinois. 
87. Sofer, G. A., R. E. Collingham, and K. V. Walters. 1988. "Implementation of an Advanced BWR Design." In Trans. Am. Nuc7. Soc. 56:119-121 (June 1988). Copyright 1988 by the American Nuclear Society, LaGrange Park, Illinois.

88. Lee, J. K., and R. G. Newsom. 1987. "Statistical Test for Consistency of Zircaloy Corrosion Resistance Properties." In Trans. Am. Nucl. Soc. 55:305-306 (November 1987). Copyright 1987 by the American Nuclear Society, LaGrange Park, I1linois.

89. Cowan, R. L. et a]. 1988. "Hydrogen Water Chemistry in Boiling Water Reactors." In Trans. Am. Nucl. Soc. 56(Supplement No. 2):63-64 (Apri 1 1988). Copyright 1988 by the American Nuclear Society, LaGrange Park, Illinois.

90. Fletcher, W. D. 1987. "Modifications of Water Chemistry for Pressurized Water Reactors." In Trans. Am. Nuc]. Soc. 55:252-254 (November 1987). Copyright 1987 by the American Nuclear Society, LaGrange Park, Illinois.

91. Eickelpasch, N., et a1. 1988. "Load Following Operation and Fuel Behaviour in German BWRs." In Proceedings of the American Nuclear Society International Topical Meeting on LWR Fuel Performance, pp. 146153, Williamsburg, Virginia, April 17-20, 1988. Copyright 1988 by the American Nuclear Society, LaGrange Park, [11inois.

(ISBN 0-89448-032-4, ANS Order No. 700131)

92. Dumont, A., and P. Bournay. 1988. "FRAgEMA Fue1 Performance Under Load Follow and Frequency Control Operation in EDF Plants." In Proceedings of the American Nuclear Society International Topical Meeting on LWR Fuel Performance, pp. 137-141, Will iamsburg, Virginia, Apri1 1720, 1988. Copyright 1988 by the American Nuclear Socjety, LaGrange Park, Illinois. (ISBN 0-89448-032-4, ANS Order No. 700131)

93. Goldstein, L., and K. D. Sheppard. 1988. "A Survey of Load Follow Experience in U.S. Light Water Reactors." In Proceedings of the American Nuclear Society International Topical Meeting on LWR Fuel Performance, pp. 127-136, Williamsburg, Virginia, April 17-20, 1988. Copyright 1988 by the American Nuclear Society, LaGrange Park, I71 inois. (ISBN 0-89448-032-4, ANS Order No. 700131)

94. Manzel, R., et a7. 1988. "Experience and Further Development with Pool-Site Inspection and Reconstitution of LWR-Fuel." In Proceedings of the American Nuclear Society International Topical Meeting on LWR Fuel Performance, pp. 311-320, Will i amsburg, Virginia, April 17-20, 1988. Copyright 1988 by the American Nuclear Society, LaGrange Park, Illinois. (ISBN 0-89448-032-4, ANS Order No. 700131) 
95. Lippens, M., and N. Cadel1i. 1988. "A European Investigation of M0X Fuel." In Proceedings of the American Nuclear Society International Topical on LWR Fuel Performance, pp. 54-65, Williamsburg, Virginia, Apri1 17-20, 1988. Copyright 1988 by the American Nuclear Society, LaGrange Park, I11inois. (ISBN 0-89448-032-4, ANS Order No. 700131)

96. Test Fuel Irradiation in $14 \times 14$ Assemblies at Calvert Cliffs, Volumes 1 and 2. FinaT Report, EPRI NP-4230M, Final Report, Copyright 1985, Electric Power Research Institute, Palo Alto, Cal ifornia, September 1985. Reprinted with permission.

97. Norman, N. A. 1987. "The Systems Approach to Spent Fuel and High-Level Nuclear Waste Managenent." In Irans. Am. Nucl. Soc. 56 (Supplement No. 1):560-566 (September 1988). Copyright 1988 by the American Nuclear Society, LaGrange Park, Illinois.

98. U.S. Nuclear Regulatory Commission. 1972. Assumptions Used for Evaluating the Potential Radiological Consequences of a Fuel Handling Accident in the Fuel Handling and Storage Facility for Boiling and Pressurized Water Reactors. Regulatory Guide 1.25, Rev. 0, Washington, D.C.

99. HuTman, L. G., U.S. Nuclear Regulatory Commission. December 20, 1982 .

Memorandum to C. H. Berlinger, U.S. Nuclear Regulatory Commission, "Reload Reviews in DSI [Division of Systems Integration]." Available in NRC Public Document Room.

100. Richland Operations Office, U.S. Department of Energy. 1987. Spent Fuel Storage Requirements 1987. DOE/RL-87-11.

101. Roberts, J. P. 1987. "Burnup Credit Considerations in Dry Spent-Fuel Storage Licensing." In Trans. Am. Nucl. Soc. 55:391 (November 1987). Copyright 1987 by the American Nuclear Socjety, LaGrange Park, ITlinois.

102. Libby, R. A, and S. R. Bierman. 1987. "Instrumentation for Measuring the Burnup of Spent Nuclear Fuel." In Trans. Am. Nucl. Soc. 55:401 (November 1987). Copyright 1987 by the American Nuclear Society, LaGrange Park, Illinois.

103. Roddy, J. W., et a1. March 1985. Physical Decay Characteristics of Commercial PWR Spent Fuel. ORNL/TM-9591/Vl and Rl. Oak Ridge National Laboratory, 0ak Ridge, Tennessee.

104. Sandoval, R. P., et al. 1988. "An Analys is of Crud Contribution to the Maximum Permissible Release Rates for Reactor Spent-Fuel Shipments." In Irans. Am. Nuc]. Soc. 56:108-109 (June 1988). Copyright 1988 by the American Nuclear Society, LaGrange Park, Illinois. 


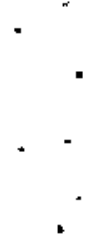

, 


\section{DISTRIBUTION}

No. of

Copies

10 DOE Technical Information Center

\section{OFFSITE}

R. Ste in

Office of Civilian Radioactive Waste Management

U.S. Department of Energy

RW-30

Washington, DC 20585

K. A. Xlein

Office of Civilian Radioactive Waste Management

U.S. Department of Energy

RW-32

Washington, DC 20585

c. Head

Office of Civilian Radioactive Waste Management

U.S. Department of Energy

$\mathrm{RW}-32$

Washington, DC 20585

C. W. Conner

Office of Civilian Radioactive Waste Management

U.S. Department of Energy

RW-33

Washington, DC 20585

J. S. Finucane

Energy Information Administration

U.S. Department of Energy

EI-53

Washington, DC 20585

L. C. Rouse

U.S. Nuclear Regulatory Commission

Spent Fuel Storage Instatlation

Division of Fuel Cycle and

Material Safety

Washington, DC 20555
No. of

Copies

2 U.S. Nuclear Regulatory Commission

Office of Nuclear Materials Safety and Safeguards

Washington, DC 20555

ATTN: F. C. Sturz

J. P. Roberts

W. R. Pearson

Regulatory Applications Division

U.S. NucTear Regulatory Commission

Mail Stop NL-007

Washington, DC 20555

C. Feldman

U.S. Nuclear Regulatory Commission Office of Nuclear Regulatory Research

Washington, DC 20555

C. Matthews

U.S. Department of Energy

Oak Ridge Operations Office

P.0. Box E

Oak Ridge, TN 37830

C. P. Gertz

Waste Management Project Office

U.S. Department of Energy

P.0. Box 98518

Las Vegas, NY 89193-8518

2 U.S. Department of Energy

Idaho Operations Office

785 DOE Place

Idaho Falls, ID 83402

ATTN: M. Fisher

S. T. Hinschberger

K. G. Golliher

U.S. Department of Energy

DOE Albuquerque Operations Office P.0. Box 5400

A1buquerque, NM 87115 
No. of

Copies

P. H. Lang

NE -42

Department of Energy

19901 Germantown Road

Germantown, MD 20874

4 T. W. Wood

Battelle Hemorial Institute

Washington Operations

2030 M. Street $-\mathrm{NW}$

Suite 800

Washington, DC 20036

H. Shaw

Waste Package Task, NNWSI

Lawrence Livermore National Laboratory

P.0. Box 808

Livermore, CA 94550

2 Electric Power Research Institute P.0. Box 10412

Palo Alto, CA 94303

ATTN: R. F. Williams

R. W. Lambert

2 Science Applications International Corporation

Valley Bank Center

101 Convention Center Drive, Suite 407

Las Vegas, NV 89109

ATTN: W. B. Andrews

R. Morissette
No. of

Copies

ONSITE

DOE Richland Dperations Office

C. E. Collantes

D. C. Langstaff

44 Pacific Northwest Laboratory

W. J. Bailey (20)

J. 0. Barner

C. E. Beyer

T. K. Campbell

M. E. Cunningham

J. M. Creer

R. E. Einziger

M. D. Freshiey

E. R. Gilbert

C. M. Heeb

A. B. Johnson, Jr.

D. D. Lanning

S. C. Marschman

M. A. McKinnon

D. J. Silviera

H. D. Smith

L. A. Strope

R. E. Walling

C. N. Wilson

Publishing Coordination

Technical Library (5) 